\title{
Comparison of GRCop-84 to Other Cu Alloys With High Thermal Conductivities
}

\author{
Henry C. de Groh III, ${ }^{1}$ David L. Ellis, ${ }^{1}$ and William S. Loewenthal' \\ ${ }^{1}$ NASA Glenn Research Center, 21000 Brookpark Road, Cleveland, OH 44135 \\ ${ }^{2}$ Ohio Aerospace Institute, 21000 Brookpark Road, Cleveland, OH 44135
}

\begin{abstract}
The mechanical properties of six highly conductive copper alloys, GRCop-84, AMZIRC, GlidCop Al-15, Cu-1Cr-0.1Zr, $\mathrm{Cu}-0.9 \mathrm{Cr}$, and NARloy-Z were compared. Tests were done on as-received hard drawn material, and after a heat treatment designed to simulate a brazing operation at $935^{\circ} \mathrm{C}$. In the as-received condition AMZIRC, GlidCop Al-15, Cu$1 \mathrm{Cr}-0.1 \mathrm{Zr}$ and $\mathrm{Cu}-0.9 \mathrm{Cr}$ had excellent strengths at temperatures below $500{ }^{\circ} \mathrm{C}$. However, the brazing heat treatment substantially decreased the mechanical properties of AMZIRC, $\mathrm{Cu}-1 \mathrm{Cr}-0.1 \mathrm{Zr}, \mathrm{Cu}-0.9 \mathrm{Cr}$, and NARloy-Z. The properties of GlidCop Al-15 and GRCop-84 were not significantly affected by the heat treatment. Thus there appear to be advantages to GRCop-84 over AMZIRC, Cu-1Cr-0.1Zr, Cu-0.9Cr, and NARloy-Z if use or processing temperatures greater than $500{ }^{\circ} \mathrm{C}$ are expected. Ductility was lowest in GlidCop Al-15 and $\mathrm{Cu}-0.9 \mathrm{Cr}$; reduction in area was particularly low in GlidCop $\mathrm{Al}-15$ above $500{ }^{\circ} \mathrm{C}$, and as- received $\mathrm{Cu}-0.9 \mathrm{Cr}$ was brittle between 500 and $650{ }^{\circ} \mathrm{C}$. Tensile creep tests were done at 500 and $650{ }^{\circ} \mathrm{C}$; the creep properties of GRCop-84 were superior to those of brazed AMZIRC, Cu-1Cr$0.1 \mathrm{Zr}, \mathrm{Cu}-0.9 \mathrm{Cr}$, and NARloy-Z. In the brazed condition, GRCop-84 was superior to the other alloys due to its greater strength and creep resistance (compared to AMZIRC, $\mathrm{Cu}-1 \mathrm{Cr}-0.1 \mathrm{Zr}, \mathrm{Cu}-0.9 \mathrm{Cr}$, and NARloy-Z) and ductility (compared to GlidCop Al-15).
\end{abstract}

Keywords GRCop-84, AMZIRC, GlidCop Al-15, Cu-Cr-Zr, Cu-Cr, NARloy-Z, Copper, compression, tension, creep, mechanical properties

\section{Introduction}

GRCop-84 (Cu-8 at\%Cr-4 at\% $\mathrm{Nb})$ is a newly-developed copper alloy with an attractive balance of high temperature strength, creep resistance, low cycle fatigue life, and thermal conductivity. Our goal is to compare GRCop-84 to similar commercial copper alloys in a consistent manner. Data on alloys such as NARloy-Z, AMZIRC, GlidCop Al-15 low oxygen grade, $\mathrm{Cu}-0.9 \mathrm{Cr}$, and $\mathrm{Cu}-1 \mathrm{Cr}-0.1 \mathrm{Zr}$ can be found in the literature. ${ }^{[1-15]}$ However, the test conditions are rarely matching for "apples-to-apples" comparisons. Most literature also deals only with as-received material. The alloys being considered in this work are used in high temperature applications where high thermal conductivity, high strength, and resistance to creep and low cycle fatigue are required. Such applications include high performance metal gaskets, rocket engine combustion chambers, nozzle liners, and various Reusable Launch Vehicle (RLV) technologies. ${ }^{[1]}$ In regeneratively cooled combustion chamber applications, such as nozzle liners, these alloys are subjected to the combustion gas temperatures on the hot side and are cooled by cryogenic hydrogen flow on the back side. The tensile, creep, low cycle fatigue, and compressive strength of GRCop-84 will be compared to those of the existing commercially available alloys shown in Table 1 . To compare the properties these alloys would actually have during use, they were tested in the as-received condition and after a heat treatment designed to simulate a typical high temperature brazing cycle often needed in the manufacturing process. ${ }^{[2]}$ The selected brazing heat treatment cycle is presented in Table 2.

GRCop-84 is a dispersion and precipitation hardened alloy made using rapid solidification and powder metallurgical techniques. Consolidation is accomplished by hot isostatic pressing (HIP) or direct extrusion. After consolidation most processing methods used with high strength copper alloys can be used to form GRCop-84, e.g., hot and cold rolling. The solubilities of $\mathrm{Cr}$ and $\mathrm{Nb}$ are very high in liquid copper but very low in solid $\mathrm{Cu}$. Chromium and $\mathrm{Nb}$ have a high affinity for each other, thus nearly all of the $\mathrm{Cr}$ and $\mathrm{Nb}$ combine to form the hardening intermetallic phase $\mathrm{Cr}_{2} \mathrm{Nb}$. This leaves a nearly pure $\mathrm{Cu}$ matrix. The high purity of the copper matrix leads to a thermal conductivity for the alloy that is 72 to $82 \%$ of that of pure oxygen-free $\mathrm{Cu}^{[3]}$

AMZIRC can be cast as well as produced using powder metallurgy. Peak strengths in AMZIRC are achieved through cold work combined with precipitation hardening and are lost if the hardened material is exposed to a high temperature braze cycle or if fully annealed. ${ }^{[4]}$ Approximately $80 \%$ of the strength gains normally achieved in AMZIRC are due to cold work, with only modest additional gains achieved upon aging. ${ }^{[5]}$ Horn and Lewis found that cold-worked AMZIRC retains much of its strength up to about $500{ }^{\circ} \mathrm{C}$ without becoming brittle. They also noted that the excellent strength of heavily worked rod was not achieved in their billets and that there was an inability to obtain uniform hardening in large billets. ${ }^{[6]}$ AMZIRC's low cycle fatigue properties have been reported by Conway et al. ${ }^{[7]}$ and by Hannum et al. ${ }^{[8]}$ and property reviews which have included AMZIRC have been 
published. ${ }^{[5,9]}$ Dalder et al. found the room temperature ultimate tensile strength of AMZIRC to be about $430 \mathrm{MPa}$ and that AMZIRC's room temperature strength dropped to $241 \mathrm{MPa}$ after exposure to $>500{ }^{\circ} \mathrm{C}$. ${ }^{[10]}$ The room temperature ductility of AMZIRC decreases with cold work, with elongation at failure going from about $50 \%$ for unworked material to $10 \%{ }^{[5]}$ or lower ${ }^{[10]}$ for material worked $>30 \%$. AMZIRC has a solution temperature near 910 ${ }^{\circ} \mathrm{C}$ and aging temperatures near $525{ }^{\circ} \mathrm{C}$ for unworked material, and $425{ }^{\circ} \mathrm{C}$ for cold worked material.

GlidCop Al-15 is dispersion hardened with very fine $\mathrm{Al}_{2} \mathrm{O}_{3}$ particles. Considerable research has been published on GlidCop Al-15. Dalder et al. ${ }^{[10]}$ found GlidCop more thermally stable than AMZIRC. Wycliffe ${ }^{[5]}$ found (in 1984) that the only copper alloys with good strength above $650{ }^{\circ} \mathrm{C}$ were oxide dispersion strengthened (ODS) alloys such as GlidCop. However, Wycliffe also noted that the ductility and low cycle fatigue properties of ODS copper alloys at elevated temperatures were poor. Stephens and Schmale showed that heat treat cycles which simulate brazing operations as high as $980{ }^{\circ} \mathrm{C}$ result in only a small decline in ultimate tensile strength $(\sim 13 \%)$ in GlidCop Al-15, and that ductility improves substantially. ${ }^{[2]}$ Stephens et al. ${ }^{[11]}$ showed that fine-grained GlidCop Al-15 that was annealed for 15 minutes at $980^{\circ} \mathrm{C}$ was stronger in room temperature tension than coarse-grained GlidCop Al- 15 annealed 100 hr. at $980{ }^{\circ} \mathrm{C}$, but that as the test temperature increased, the advantage fine-grained GlidCop Al-15 had vanished, until at $800{ }^{\circ} \mathrm{C}$ coarse-grained GlidCop Al-15 was stronger than fine-grained GlidCop Al-15. In work due to Conway et al. the ductility and low-cycle-fatigue properties of GlidCop were found to be low; however, the alloy tested is noted as GlidCop Al-10, which contains $0.2 \mathrm{wt} \% \mathrm{Al}_{2} \mathrm{O}_{3}{ }^{[4]}$ versus $0.32 \mathrm{wt} . \% \mathrm{Al}_{2} \mathrm{O}_{3}$ for GlidCop Al-15.

$\mathrm{Cu}-0.9 \mathrm{Cr}$ is precipitation strengthened by elemental $\mathrm{Cr}$ precipitates and is known for excellent cold workability. Precipitation hardening for these alloys consists of solution treatments near $990{ }^{\circ} \mathrm{C}$ for about 20 minutes, water quenching, and aging near $460{ }^{\circ} \mathrm{C}$ for about 3 hours. ${ }^{[12]} \mathrm{Near}$ peak strength in $\mathrm{Cu}-0.9 \mathrm{Cr}$ alloys is sometimes achieved during processing, due either to cold work, or precipitation hardening at process temperatures. In such cases only moderate gains in strength are possible with aging heat treatments. ${ }^{[13]}$ The ductility of these alloys near the expected use temperatures of 400 to $600^{\circ} \mathrm{C}$ has been found to be poor compared to other copper alloys. ${ }^{[5,6]}$ Room temperature strength in $\mathrm{Cu}-0.9 \mathrm{Cr}$ alloys is good, with UTS values near $500 \mathrm{MPa} \cdot{ }^{[4,5,6]}$ Strength declines with increasing temperature, particularly steeply as $427^{\circ} \mathrm{C}$ is exceeded, with UTS values near $65 \mathrm{MPa}$ at $593{ }^{\circ} \mathrm{C} .{ }^{[5,6]}$

$\mathrm{Cu}-1 \mathrm{Cr}-0.1 \mathrm{Zr}$ is age hardenable, with $\mathrm{Cr}$ and $\mathrm{Cu}_{5} \mathrm{Zr}$ precipitates. ${ }^{[16]}$ Pratt \& Whitney presented work on an alloy, $\mathrm{Cu}-1 \mathrm{Cr}-0.5 \mathrm{Zr}$, which was found it to be very strong, but to have poor low cycle fatigue at $705{ }^{\circ} \mathrm{C}$ compared to NARloy-Z and a $\mathrm{Cu}-0.47 \mathrm{wt} \% \mathrm{Zr}$ alloy (which is close to the composition of AMZIRC). ${ }^{[17]}$ The literature data indicates that at $538{ }^{\circ} \mathrm{C}$, on the basis of total axial strain range versus number of cycles to failure, the fatigue properties of AMZIRC, and $\mathrm{Cu}-\mathrm{Zr}$ alloys are better than those of $\mathrm{Cu}-\mathrm{Cr}$, NARloy-Z, and GlidCop Al-10. ${ }^{[4,5,7]}$ Ultimate and yield strengths at $705^{\circ} \mathrm{C}$ for as-received material were approximately 175 and 94 MPa respectively. Tensile properties for $\mathrm{Cu}-\mathrm{Cr}-\mathrm{Zr}$ alloys are also reported by Zinkle ${ }^{[18]}$ The solution and aging temperatures for $\mathrm{Cu}-$ $1 \mathrm{Cr}-0.1 \mathrm{Zr}$ are expected to be similar to AMZIRC and $\mathrm{Cu}-0.9 \mathrm{Cr}$. The solution and aging temperatures for $\mathrm{Cu}-0.9 \mathrm{Cr}$ are approximately 990 and $440{ }^{\circ} \mathrm{C}$ respectively. The effectiveness of aging also depends on quench rates from solution temperatures. Relations between quench rates and hardenability in the $\mathrm{Cu}-1 \mathrm{Cr}-0.1 \mathrm{Zr}$ alloy were also examined as part of this work but are reported elsewhere.

Although no new tests were done with the alloy known as NARloy-Z, for completeness, data was drawn from the literature and included in some figures and comparisons to the other alloys. NARloy- $\mathrm{Z}$ is a $\mathrm{Cu}-3 \mathrm{Ag}-0.5 \mathrm{Zr}$ alloy that is currently used in NASA's Space Shuttle Main Engines. A chemically equivalent alloy known as NASA-Z has been used by Aerojet as a liner material in several of Aerojet's rocket combustion chambers. ${ }^{[14]}$ These copper-silverzirconium alloys are typically solution treated, water quenched, and aged for maximum strength, forming zirconium and silver rich precipitates. Nguyentat, Gibson and Horn have examined relations among quench rates from the solution temperature. ${ }^{[14]}$ Hardness and yield strength declined by a factor of 3 when water quench rates from the solution temperature were decreased to those achieved through furnace cooling, however ultimate tensile strength declined only about $13 \%$. Room temperature maximum ultimate tensile strengths for NARloy-Z and NASA-Z are typically $320 \mathrm{MPa}$, with yield strengths around $170 \mathrm{MPa}{ }^{[3,9,14,15,19]}$ these have been shown to decline as a result of exposure to high temperatures, such as due to a brazing heat treatment. The yield strength of NARloy-Z after a brazing heat treatment has been found to be approximately $80 \mathrm{MPa}$ at $100{ }^{\circ} \mathrm{C}^{[3]}$

\section{Test Procedures}

The test plan included tensile, compressive, creep, thermal expansion and low-cycle fatigue properties of all the alloys. Low-cycle fatigue results will be presented elsewhere. Detailed testing procedures have been presented previously ${ }^{[20-23]}$ and will be only briefly outlined here. 
All alloys were tested in both the as-received condition and after a simulated braze treatment. GRCop- 84 was tested in two as-received conditions: as-extruded, and as-HIPed. AMZIRC, GlidCop $\mathrm{Al}-15, \mathrm{Cu}-1 \mathrm{Cr}-0.1 \mathrm{Zr}$, and $\mathrm{Cu}-$ $0.9 \mathrm{Cr}$ alloys were received in the form of hard drawn rods that were $3 / 8$ to $3 / 4$ inch diameter. Table 2 shows the simulated braze cycle designated "Braze 935" which is meant to be typical of a main combustion chamber liner/jacket brazing operation.

\section{Tensile and Creep Procedures}

Tensile and compression tests were conducted at $25,200,500,650$, and $800{ }^{\circ} \mathrm{C}(77,392,932,1202$, and 1472 ${ }^{\circ} \mathrm{F}$ ) using strain rate control. Tests at elevated temperatures employed flowing $\mathrm{Ar}$ at $2.5 \mathrm{l} / \mathrm{min}$. A strain rate of 0.005 $\mathrm{mm} / \mathrm{mm} / \mathrm{min}\left(8.3 \times 10^{-5} \mathrm{sec}^{-1}\right)$ was used in both tensile and compression tests. Strain was measured via an extensometer attached to the gage of the tensile samples, but compression tests relied on crosshead displacement. Specimen dogbones used for AMZIRC, $\mathrm{Cu}-1 \mathrm{Cr}-0.1 \mathrm{Zn}$, and $\mathrm{Cu}-0.9 \mathrm{Cr}$ tensile and creep tests had a gauge diameter and length of $5.84 \mathrm{~mm}(0.23 \mathrm{in})$ and $29.06 \mathrm{~mm}$ (1.144 in) respectively. Tensile and creep GlidCop Al-15 specimens used a gauge diameter and length of $9.02 \mathrm{~mm}(0.355 \mathrm{in})$ and $40.82 \mathrm{~mm}$ (1.607 in) respectively. Compression specimens were cylinders of $5.0 \mathrm{~mm}$ ( $0.197 \mathrm{in})$ diameter by $10 \mathrm{~mm}$ (0.394 in) long.

Creep tests were done in vacuum at 500,650 , and $800^{\circ} \mathrm{C}$ using constant load lever arm vacuum creep units. The stresses in the creep tests were varied to give lives equivalent to 100 Space Shuttle missions (15 hours). For GRCop84 creep stresses were about $100 \mathrm{MPa}$ at $500{ }^{\circ} \mathrm{C}, 40 \mathrm{MPa}$ at $650{ }^{\circ} \mathrm{C}$, and $20 \mathrm{MPa}$ at $800{ }^{\circ} \mathrm{C}$. Stress levels for the other alloys typically had to be lower to achieve lives near 15 hours.

Creep testing of all alloys except GRCop-84 started with step loading vacuum creep tests using a converted Instron tensile test load frame. The load was held constant for five hours, and then raised a set amount every five hours for a total of 20 steps, or until failure. All creep tests were performed with at least two thermocouples attached to the ends of the gage area. For these creep tests, strain was measured by monitoring crosshead movement. All creep rates were defined as the slope of the linear portion of the creep strain-time curve between primary and tertiary creep.

In an effort to include previous constant load GRCop-84 creep tests, we have statistically modified some older GRCop-84 data to make it consistent with the methods used in this study. These data were then used to determine power law creep coefficients for comparison to the other alloys (see Table 4). The details of the statistical processing are in Ref. 24. These creep rate equations for GRCop- 84 were plotted with the constant load creep data in Fig. 16.

\section{Thermal Expansion Procedures}

Thermal expansion of the candidate alloys was conducted using an Anter Unitherm 1161AL-V vertical two head pushrod dilatometer. Resolution of the displacement was $0.001 \mathrm{~mm}$. A sample was loaded along with a Pt standard, and the chamber sealed. The chamber was evacuated and purged with argon several times to remove the oxygen from the chamber. During the final purge the pressure was reduced to $\leq 39 \mathrm{~Pa}$ (300 millitorr) prior to backfilling with Ar. Ar was selected over He based upon the tendency of Ar to collect at the bottom of the chamber and displace any residual oxygen in the vicinity of the sample.

The samples were heated to $1000{ }^{\circ} \mathrm{C}$ using a heating rate of $3{ }^{\circ} \mathrm{C}$ per minute and then cooled to room temperature while the changes in length for both the copper alloy sample and Pt standard were measured. During cooling the rate was $3{ }^{\circ} \mathrm{C}$ per minute until the temperature reached approximately $175^{\circ} \mathrm{C}$. At that point the samples underwent free cooling. Ar was flowing through the chamber during the test at a rate of approximately $50 \mathrm{~cm}^{3}$ per minute. This maintained the chamber at a slight positive pressure. Oxidation of the samples was minimal and did not affect the results. Each sample was given five cycles. Two samples of each alloy were tested.

During the test the displacement and temperature for both samples were measured simultaneously. Using the sample temperature and reference data for the thermal expansion of $\mathrm{Pt}^{[25]}$ the actual displacement from the $\mathrm{Pt}$ sample's thermal expansion could be calculated for each data point. Subtracting this value from the measured displacement of the Pt sample allowed the calculation of the contribution of the thermal expansion of the alumina push rod and sample holder to the observed displacements. The contribution of the holder and push rod was then subtracted from the measured copper alloy displacement to calculate the actual thermal expansion of the $\mathrm{Cu}$ alloy sample at each data point. To calculate the thermal expansion strain, the displacement was divided by the original sample length. The data was then plotted and fitted with a second order polynomial equation. The thermal expansion of each specimen was measured five times, the results of these five cycles were averaged, and then the results of two specimens were averaged to yield the final empirical relations between thermal expansion and temperature. 


\section{Test Results}

\section{Microstructures}

Figure 1 shows typical as-extruded GRCop- 84 microstructure. The as-HIPed and brazed microstructures are visually indistinguishable from the as-extruded microstructure. GRCop-84 gains most of its added strength over pure copper from finely dispersed $\mathrm{Cr}_{2} \mathrm{Nb}$ precipitates such as those shown in Fig. 1. The stability and melting point of $\mathrm{Cr}_{2} \mathrm{Nb}$ is so high that it begins to precipitate in the molten GRCop-84 before the onset of primary $\mathrm{Cu}$ solidification. ${ }^{[26]}$ These stable $\mathrm{Cr}_{2} \mathrm{Nb}$ precipitates do not significantly coarsen during the brazing heat treatment or during use at high temperatures.

Figures 2 and 3 show the as-received and post brazed microstructures for AMZIRC. In Fig. 3 it can be see that the fine, elongated grain structure observed in as-received hard drawn AMZIRC (Fig. 2) has given way to a much coarser structure of equiaxed grains with some twinning indicative of complete recrystallisation and considerable grain growth. The observed twinning is common for FCC metals during recrystallization. ${ }^{[27]}$ Rather large $(\sim 5 \mu \mathrm{m})$ precipitates are present in both as-received and brazed structures. These precipitates are believed to be high temperature $\mathrm{Cu}_{5} \mathrm{Zr}$ intermetallics formed during casting and not solutionized at the brazing temperature or at the solution temperatures normally used for AMZIRC $\left(980^{\circ} \mathrm{C}\right)$.

The recrystallized grains in the brazed AMZIRC are essentially strain free. This lower dislocation density contributes to the decline in strength upon brazing as does the larger grain size through a Hall-Petch relationship. ${ }^{[27]}$

Figures 4 and 5 show the as-received and post brazed microstructures of GlidCop Al-15. As was the case for GRCop-84, the microstructure of GlidCop appears to be unaffected by the simulated braze heat treatment.

Figures 6 and 7 show the microstructures of as-received and post brazed $\mathrm{Cu}-1 \mathrm{Cr}-0.1 \mathrm{Zr}$. The as-received $\mathrm{Cu}-1 \mathrm{Cr}-$ $0.1 \mathrm{Zr}$ has a fine grain structure, elongated along the drawing direction. The brazed material has recrystallized; but the grain size appears to have remained small, maybe even decreased compared to the as-received $\mathrm{Cu}-1 \mathrm{Cr}-0.1$ material. Thus the presence of $\mathrm{Cr}$ in the alloy prevented the extensive grain growth observed in AMZIRC after recrystallisation. What we believe to be $\mathrm{Cr}$ and $\mathrm{Cu}_{5} \mathrm{Zr}$ precipitates can be seen in the high magnification micrographs (Figs. 6(b), and 7(b)). The $\mathrm{Cu}_{5} \mathrm{Zr}$ precipitates, which have a melting point near $1030{ }^{\circ} \mathrm{C}$, have an alignment due to the drawing process; since this alignment persists in the brazed microstructure it is concluded that the $\mathrm{Cu}_{5} \mathrm{Zr}$ precipitates are not solutionized at the $935^{\circ} \mathrm{C}$ brazing temperature, which is consistent with the ternary $\mathrm{Cu}-\mathrm{Cr}-\mathrm{Zr}$ phase diagram of Zeng et al. ${ }^{[16]}$

The $\mathrm{Cu}-0.9 \mathrm{Cr}$ structures shown in Figs. 8 and 9 appear nearly identical to those seen in $\mathrm{Cu}-1 \mathrm{Cr}-0.1 \mathrm{Zr}$, with the structure of the $\mathrm{Cu}-0.9 \mathrm{Cr}$ alloy consisting of fine, slightly elongated grains and $\mathrm{Cr}$ precipitates in the as-received microstructures. The braze appears to have caused recrystallization (Fig. 9) but extensive grain growth did not occur, as it did in the case of AMZIRC. The aligned precipitates in the as-received structure (Fig. 8(b)) appear much more spherical after brazing (Fig. 9(b)).

\section{Tensile and Compression Tests}

Room and elevated temperature tensile and compressive properties for the alloys are presented in Figs. 10 through 18. In Figs. 10 through 13, data points shown for GRCop-84 are from an average of five tests. Data points for AMZIRC are from the average of two tests except at the temperatures of $400,500,600$, and $650{ }^{\circ} \mathrm{C}$ which were single tests. The data points for GlidCop $\mathrm{Al}-15, \mathrm{Cu}-1 \mathrm{Cr}-0.1 \mathrm{Zr}$, and $\mathrm{Cu}-0.9 \mathrm{Cr}$ were from the average of two tests. The compression data shown in Fig. 14 were averaged from two or three tests. Tables containing these data are presented in Ref. 20.

The ultimate and yield strengths shown in Figs. 10 and 11 indicate that in the as-received condition the competing alloys, AMZIRC, GlidCop, $\mathrm{Cu}-1 \mathrm{Cr}-0.1 \mathrm{Zr}$, and $\mathrm{Cu}-0.9 \mathrm{Cr}$ are generally stronger than GRCop- 84 . However, after the simulated brazing heat treatment, the strength of AMZIRC, $\mathrm{Cu}-1 \mathrm{Cr}-0.1 \mathrm{Zr}$ and $\mathrm{Cu}-0.9 \mathrm{Cr}$ drop dramatically to strength levels significantly below GRCop-84. GlidCop Al-15 retains most of its strength after the brazing heat treatment making it stronger than GRCop- 84 in tensile tests at all temperatures and conditions examined. NARloy-Z's ultimate strength is similar to GRCop-84's, however NARloy-Z's yield strength is lower, particularly after brazing. There is an abrupt drop in the strength of as-received AMZIRC near $500{ }^{\circ} \mathrm{C}$ which appears to coincide with the onset of annealing and recrystallization. The strength of $\mathrm{Cu}-1 \mathrm{Cr}-0.1 \mathrm{Zr}$ and $\mathrm{Cu}-0.9 \mathrm{Cr}$ drop more gradually as test temperatures are increased compared to AMZIRC. The trends apparent in the tensile strengths of the alloys are mirrored in compression as shown in Fig. 14.

All failures were ductile except those for $\mathrm{Cu}-0.9 \mathrm{Cr}$ at temperatures between 500 and $650{ }^{\circ} \mathrm{C}$. At these temperatures the ductility of $\mathrm{Cu}-0.9 \mathrm{Cr}$ was the lowest of all the alloys, with elongation and reduction in area being approximately 2 and $6.7 \%$ respectively. Exposing as-received AMZIRC to temperatures above $500{ }^{\circ} \mathrm{C}$ 
approximately tripled elongation, resulting in the highest elongations of any of the alloys (Fig. 12). GRCop-84 and GlidCop Al-15 had approximately the same elongation. In general, it was found that as the testing temperature increased, uniform elongation increased and localized necking decreased which decreased the reduction in area measurements (R/A) as shown in Fig. 13. At temperatures above $500{ }^{\circ} \mathrm{C}$ reduction in area was higher for GRCop- 84 compared to GlidCop Al-15.

\section{Creep Tests}

Results of step loading creep tests are shown in Fig. 15. Constant load creep results are shown in Fig. 16. All creep rates, or strain rates measured during creep tests, were defined as the linear portion of the time - strain data after load up and primary creep but before tertiary creep.

It can be seen in Fig. 15 that at a given stress at $500{ }^{\circ} \mathrm{C}$ the steady-state creep rate of as-received AMZIRC is about double that of GRCop-84, and the strain rate of brazed AMZIRC is about two orders of magnitude greater than GRCop-84. Similarly, strain rates of AMZIRC at $650{ }^{\circ} \mathrm{C}$ at a stress of $20 \mathrm{MPa}$ are about two orders of magnitude greater than the strain rates observed for GRCop- 84 at $650{ }^{\circ} \mathrm{C}$ and $20 \mathrm{MPa}$. NARloy- $\mathrm{Z}$ and $\mathrm{Cu}-0.9 \mathrm{Cr}$ also performed much worse than GRCop- 84 in creep. In the as-received condition GlidCop-Al15 and $\mathrm{Cu}-1 \mathrm{Cr}-0.1 \mathrm{Zr}$ performed better than GRCop-84, however, $\mathrm{Cu}-1 \mathrm{Cr}-0.1 \mathrm{Zr}$ 's creep properties suffered after brazing.

From our experience, a creep rate of about $5 \times 10^{-6} \mathrm{sec}^{-1}$ often yields a creep rupture life of about 15 hours assuming most of the creep life is spent in second stage or steady-state creep. Step loaded and constant load creep tests indicate that at $500{ }^{\circ} \mathrm{C}$ stresses of about 65 and $130 \mathrm{MPa}$ applied to brazed AMZIRC and GRCop-84 respectively are expected to yield approximately, 15 hour lives (Figs. 15 and 16). Thus for equivalent temperatures and lives, GRCop- 84 can sustain about double the creep stress compared to brazed AMZIRC. Note how close together the GRCop- $84\left(650{ }^{\circ} \mathrm{C}\right)$ and brazed AMZIRC $\left(500{ }^{\circ} \mathrm{C}\right)$ curves are in Fig. 15. This indicates that at equivalent stress and strain rate, such as $\sigma=47 \mathrm{MPa}$ and $\dot{\varepsilon}=10^{-6} \mathrm{sec}^{-1}$, GRCop-84 can operate at temperatures 150 ${ }^{\circ} \mathrm{C}$ higher than AMZIRC. GlidCop Al-15 performed very well, with creep rates much lower (at a given stress) than any of the other alloys at $500{ }^{\circ} \mathrm{C}$. As-received $\mathrm{Cu}-1 \mathrm{Cr}-0.1 \mathrm{Zr}$ also performed very well in creep, however, after brazing, creep properties declined substantially such that GRCop- 84 was found to withstand double the stress at equivalent strain rates at $650^{\circ} \mathrm{C}$.

Often creep can be described by a rate equation of the form $\dot{\varepsilon}=A \sigma^{n}$, where $\dot{\varepsilon}$ is creep strain rate, $A$ is a constant, $\sigma$ is creep stress, and $n$ is the stress exponent. The power law creep constants for the step loaded creep tests and those resulting from the constant load creep tests were independently determined and are presented in Tables 3 and 4 . The stress exponent $n$ can help to identify creep mechanisms ${ }^{[28]}$ for example, dispersion strengthened materials commonly have high stress exponents, of the order of 20 to 100 due to the added resistance to dislocation glide caused by the particles. Before such an exploration of creep mechanisms, trends in our data, and areas where more data are needed will be examined. The creep stress exponents $n$ for GRCop- 84 at 500,650 and $800{ }^{\circ} \mathrm{C}$ were fairly consistent, equal to about 9.5 in the step loaded creep tests, and 8 for constant load creep. ${ }^{[2]}$ The stress exponents for GlidCop ranged from 12.4 to 91.2 (see Tables 3 and 4) and the exponents resulting from step loaded creep (Table 3) were consistently and significantly lower than the exponents resulting from constant load creep (Table 4). The stress exponents for AMZIRC averaged about 5.3 (with a range of 2.35 to 9.49), $n$ averaged about 5.1 for the $\mathrm{Cu}-1 \mathrm{Cr}-0.1 \mathrm{Zr}$ creep tests, and the average stress exponent for the $\mathrm{Cu}-0.9 \mathrm{Cr}$ tests was 4.4.

\section{Thermal Expansion}

Thermal expansion results are presented in Fig. 17 and Table 5. Figure 17 shows plots of the equations presented in Table 5. The best fit equation for GRCop- 84 with two-way confidence intervals taken from Ref. 29 is:

$$
\alpha(T)=\left(-0.3287+2.265 \times 10^{-4} T^{1.285}\right) \pm t\left(1-\frac{\alpha}{2}, 10\right) \sqrt{\left(1.403 \times 10^{-2}\right)^{2}+\left(2.038 \times 10^{-5} \mathrm{~T}\right)^{2}}
$$

where $T$ is in Kelvin, $t(1-\alpha / 2,10)$ is the value for the $t$-distribution with 10 degrees of freedom associated with $1-\alpha / 2$ cumulative probability, and $\alpha(T)$ is the thermal expansion of GRCop- 84 in percent $(\alpha(T) / 100 \%$ is plotted in Fig. 17). The four alloys being compared to GRCop- 84 have about the same thermal expansion. This is expected since they are all near $99 \% \mathrm{Cu}$. GRCop- 84 however has about 14 vol. $\% \mathrm{Cr}_{2} \mathrm{Nb}$ which retards temperature driven strains, and results in thermal expansion being between 7 and 15\% lower for GRCop- 84 than the other alloys at typical liner hot wall temperatures. 


\section{Discussion}

\section{Comparison of Properties}

Desirable properties for copper alloys being developed for rocket engine components include: low thermal expansion; high strength; high ductility; ease of processing; low creep rate; high compressive strength; high lowcycle-fatigue strength; high maximum operating temperature; and a minimum affect caused by component manufacture such as brazing. The data presented in this paper and the literature were considered in the comparison of GRCop-84 to the other alloys. A summary of this comparison is presented in Table 6.

High temperature creep in alloys involves the interaction of the stress fields of moving dislocations with those of stationary dislocations and other boundaries such as second phase particles and grain boundaries. Specific values of the stress exponent $n$ are associated with particular creep mechanisms. Alloys that that exhibit pure metal (or "class M") behavior are characterized by $n=4$ to 8 ; exponent values in this range can be taken as evidence that the creep mechanism is dominated by dislocation climb. A majority of the creep data indicates that AMZIRC, $\mathrm{Cu}-0.9 \mathrm{Cr}$, and $\mathrm{Cu}-1 \mathrm{Cr}-0.1 \mathrm{Zr}$ have stress exponents in this range, indicating dislocation climb, or class $\mathrm{M}$, creep.

Due to added interactions between dislocations and fine particles, dispersion strengthened materials usually have stress exponents of the order of 10 to 100 . This enhanced sensitivity to stress is believed to be due to the added energy required for dislocations to climb out of their glide planes to overcome the particles and the thermally activated release of those dislocations from the departure side of the particles. ${ }^{[28]}$ GlidCop Al-15 had $n$ values between 12 and 91, which are considered to be characteristic of dispersion strengthened alloys. Though data was limited, GRCop-84 had stress exponents in the range of 7.3 to 10, implying class M creep behavior (dislocation climb) with some added stress sensitivity resulting from the relatively large volume fraction of precipitates and grain boundaries.

Refer to Table 6 for comparisons of thermal conductivity and expansion, tensile and compressive strength, ductility, creep, and the effects of brazing on the alloys.

\section{Microstructure-Property Relations}

Microstructures are shown in Figs. 1 through 9. The large number of $\mathrm{Cr}_{2} \mathrm{Nb}$ precipitates present in GRCop-84 (Fig. 1) result in good strength, and since the precipitates are stable and do not significantly coarsen, properties decline moderately with increasing temperature. The same can be said for GlidCop Al-15 (Figs. 4 and 5) microstructurally, though the precipitate is alumina. The microstructural feature that dominates properties in GRCop- 84 and GlidCop is the stable precipitates. These precipitates enabled GRCop- 84 and GlidCop to perform significantly better than the precipitation strengthened alloys in the brazed condition in both strength and creep.

By contrast, the microstructure of AMZIRC is dominated by the fine elongated grain boundaries and the benefits of work hardening (Figs. 2 and 3). Though the as-received microstructures of $\mathrm{Cu}-1 \mathrm{Cr}-0.1 \mathrm{Zr}$ and $\mathrm{Cu}-0.9 \mathrm{Cr}$ had some grain texturing characteristic of longitudinally drawn material, this elongation of fine grains was by far the most pronounced in AMZIRC; these fine textured grains, combined with precipitation hardening, result in excellent asreceived strengths at temperatures below $500{ }^{\circ} \mathrm{C}$ in AMZIRC. Precipitates in as-received AMZIRC appear coarser than those present in $\mathrm{Cu}-1 \mathrm{Cr}-0.1 \mathrm{Zr}$ which likely contributes to the higher strength in $\mathrm{Cu}-1 \mathrm{Cr}-0.1 \mathrm{Zr}$. Figure 3 shows this fine grain structure in AMZIRC is destroyed at brazing temperatures, and Fig. 10 shows the resulting drop in strength.

The microstructures of as-received and brazed $\mathrm{Cu}-1 \mathrm{Cr}-0.1 \mathrm{Zr}$ and $\mathrm{Cu}-0.9 \mathrm{Cr}$ look nearly identical. Recrystallisation appears to have occurred in AMZIRC, $\mathrm{Cu}-1 \mathrm{Cr}-0.1 \mathrm{Zr}$, and $\mathrm{Cu}-0.9 \mathrm{Cr}$ during brazing, but, subsequent grain growth and coarsening occurred in AMZIRC only. Chromium appears to have prevented significant grain growth during brazing in the $\mathrm{Cu}-1 \mathrm{Cr}-0.1 \mathrm{Zr}$ and $\mathrm{Cu}-0.9 \mathrm{Cr}$ alloys. The finer post braze microstructures in $\mathrm{Cu}-1 \mathrm{Cr}-0.1 \mathrm{Zr}$ and $\mathrm{Cu}-0.9 \mathrm{Cr}$ appear to help little in terms of improved properties. The coarser brazed AMZIRC has about the same strength and creep properties as $\mathrm{Cu}-1 \mathrm{Cr}-0.1 \mathrm{Zr}$ and $\mathrm{Cu}-0.9 \mathrm{Cr}$. The differences that stand out among brazed $\mathrm{Cu}-1 \mathrm{Cr}-0.1 \mathrm{Zr}, \mathrm{Cu}-0.9 \mathrm{Cr}$, and AMZIRC are: AMZIRC has the lowest yield strength (though ultimate strengths are similar); $\mathrm{Cu}-0.9 \mathrm{Cr}$ has significantly poorer creep properties; and as-received $\mathrm{Cu}-0.9 \mathrm{Cr}$ had markedly inferior ductility.

\section{Property Implications on Alloy Selection}

The heat treatable alloys (AMZIRC, $\mathrm{Cu}-1 \mathrm{Cr}-0.1 \mathrm{Zr}$, and $\mathrm{Cu}-0.9 \mathrm{Cr}$ ) have excellent as-received properties. The exceptions observed in this work were that $\mathrm{Cu}-0.9 \mathrm{Cr}$ and $\mathrm{NARloy}-\mathrm{Z}$ have relatively poor creep properties in the asreceived and brazed conditions compared to all the other alloys. NARloy-Z had the lowest as-received yield strength 
and was weakened substantially after brazing. Thus if use temperatures are below $500{ }^{\circ} \mathrm{C}$, and no high temperature $\left(>500{ }^{\circ} \mathrm{C}\right)$ processing is required for the alloy, AMZIRC and $\mathrm{Cu}-1 \mathrm{Cr}-0.1 \mathrm{Zr}$ are advantageous.

The high temperature stability of GlidCop Al-15 and GRCop-84 resulted in superior properties compared to the other alloys in the brazed condition. Ultimate and yield strengths, compressive yield strength, and creep stress at a given strain rate were all about two to three times greater in GlidCop and GRCop-84 compared to the other alloys after the simulated braze heat treatment. Thus if use or processing temperatures in excess of $500{ }^{\circ} \mathrm{C}$ are expected, GlidCop Al-15 and GRCop- 84 have solid advantages in strength and creep over AMZIRC, $\mathrm{Cu}-1 \mathrm{Cr}-0.1 \mathrm{Zr}, \mathrm{Cu}-0.9 \mathrm{Cr}$, and NARloy-Z.

It may be possible to regain some of the strength lost during the brazing operation in the heat treatable alloys if the alloy is quenched rapidly enough from the brazing temperature (which is also acting as the solution temperature). This might nullify the post braze advantages noted for GlidCop and GRCop-84, but only for use temperatures below $500{ }^{\circ} \mathrm{C}$, or for shot term use near $500{ }^{\circ} \mathrm{C}$. This issue is discussed in more detail elsewhere. ${ }^{[20]}$

\section{Summary and Conclusions}

In the as-received condition at $<500{ }^{\circ} \mathrm{C}$, AMZIRC, GlidCop $\mathrm{Al}-15, \mathrm{Cu}-1 \mathrm{Cr}-0.1 \mathrm{Zr}$, and $\mathrm{Cu}-0.9 \mathrm{Cr}$ were all stronger in tension and compression than GRCop-84. However, after a simulated braze heat treatment at $935^{\circ} \mathrm{C}$, the strengths of the precipitation strengthened AMZIRC, $\mathrm{Cu}-1 \mathrm{Cr}-0.1 \mathrm{Zr}, \mathrm{Cu}-0.9 \mathrm{Cr}$ and NARloy- $\mathrm{Z}$ drop to levels significantly below the strength of GRCop-84 at all temperatures. The strength of dispersion strengthened GlidCop Al-15 was largely unaffected by the heat treatment at $935^{\circ} \mathrm{C}$, thus GlidCop retained strength levels above those of GRCop-84 at all temperatures.

Ductility was lowest in as-received $\mathrm{Cu}-0.9 \mathrm{Cr}$. Ductility was also low for GlidCop Al-15 and in HIPed GRCop84. The reduction in area was particularly low in GlidCop Al-15 above $500{ }^{\circ} \mathrm{C}$. Cu-1Cr-0.1Zr and AMZIRC had much greater reductions in area and elongations than the other alloys.

Creep properties were best for as-received $\mathrm{Cu}-1 \mathrm{Cr}-0.1 \mathrm{Zr}$ and GlidCop $\mathrm{Al}-15$ and worst for $\mathrm{Cu}-0.9 \mathrm{Cr}$ and NARloy-Z. After the simulated braze at $935{ }^{\circ} \mathrm{C}$ GRCop- 84 and GlidCop had markedly better creep properties compared to the other alloys. At equivalent stress and strain rates, GRCop- 84 showed a $150{ }^{\circ} \mathrm{C}$ advantage over AMZIRC in the brazed condition. Alternatively, at equivalent temperature and strain rates, GRCop- 84 was twice as strong as brazed AMZIRC. Our tests indicate GlidCop Al-15 to be more resistant to creep at $500{ }^{\circ} \mathrm{C}$ than GRCop84, with creep rates two orders of magnitude lower than GRCop-84's at equivalent stress. This work has found that:

- After brazing, GRCop-84 and GlidCop Al-15 are stronger than AMZIRC, $\mathrm{Cu}-1 \mathrm{Cr}-0.1 \mathrm{Zr}, \mathrm{Cu}-0.9 \mathrm{Cr}$, and NARloy-Z;

- After brazing, GRCop-84 and GlidCop Al-15 are superior to AMZIRC, $\mathrm{Cu}-1 \mathrm{Cr}-0.1 \mathrm{Zr}, \mathrm{Cu}-0.9 \mathrm{Cr}$, and NARloy-Z in high temperature creep;

- Due to better ductility and processing characteristics GRCop-84 has advantages over GlidCop Al-15;

- The heat treatment used might be a worst case example for the heat treatable alloys (AMZIRC, $\mathrm{Cu}-1 \mathrm{Cr}-$ $0.1 \mathrm{Zr}$, and $\mathrm{Cu}-0.9 \mathrm{Cr}$ ). Although strength gained from cold work will be lost at brazing temperatures, it might be possible to recuperate some strength by combining solutionizing, quenching and aging cycles with the brazing operation.

\section{Acknowledgements}

We would like to praise and acknowledge the dedicated support of our technicians and machine shop personnel: John Zoha, Sharon Thomas, Bill Armstrong, John Juhas, Adrienne Veverka, Ronald Phillips, Dave Brinkman, Aldo Panzanella, and Tim Ubienski; as well as our furnace/heat treat engineer Mark Jaster. Their support has enabled timely progress on this effort.

\section{References}

1. D.T. Butler Jr. and M.J. Pindera, "Analysis of Factors Affecting the Performance of RLV Thrust Cell Liners," NASA/CR2004-213141, Aug. 2004.

2. J.J. Stephens and D.T. Schmale, "The effect of high temperature braze thermal cycles on mechanical properties of a dispersion strengthened copper alloy," SAND87-1296•UC-20, 1987, 1988 second printing.

3. M.V. Nathal, D.L. Ellis, W.S. Loewenthal, S.V. Raj, L.U. Thomas-Ogbuji, J. Ghosn, L.A. Greenbauer-Seng, J. Gayda, and C.A. Barrett, "High conductivity materials for high heat flux applications in space propulsion systems," JANNAF $39^{\text {th }}$ $\mathrm{CS} / 27^{\text {th }}$ APS $/ 21^{\text {st }}$ PSHS $/ 3^{\text {rd }}$ MSS Subcommittee Joint Meeting, Colorado Springs, CO, CD-ROM, (Dec. 2003), p. 2003$0390 \mathrm{cc}$. 
4. J.B. Conway, R.H. Stentz, and J.T. Berling, "High temperature, low cycle fatigue of copper-base alloys in argon; Part IPreliminary results for 12 alloys at $1000^{\circ} \mathrm{F}\left(538^{\circ} \mathrm{C}\right)$," NASA CR-121259, 1973.

5. P.A. Wycliffe, "Literature search on high conductivity copper based alloys," Final Report IDWA No. 6458-2, Rockwell International Sci. Center, R5739TC/sn, 1984.

6. D.D. Horn and H.F. Lewis, "Property Investigation of Copper Base Alloys at Ambient and Elevated Temperatures," AEDCTR-65-72, 1965, (Defense Document Center No. 467015) p. 4, 11, 12, 35, 38.

7. J.B. Conway, R.H. Stentz, and J.T. Berling, "High-Temperature, Low-Cycle Fatigue of Copper-Base Alloys for Rocket Nozzles, Part II-Strainrange Partitioning and Low-Cycle Fatigue Results at 538 ${ }^{\circ}$ C," NASA CR-135073, 1976.

8. N.P. Hannum, H.J. Kasper, and A.J. Pavli, "Experimental and Theoretical Investigation of Fatigue Life in Reusable Rocket Thrust Chambers," AIAA/SAE 12 $2^{\text {th }}$ Propulsion Conf., AIAA Paper No. 76-685, 1976.

9. J.J. Esposito and R.F. Zabora, "Thrust Chamber Life Prediction-Vol. I-Mechanical and Physical Properties of High Performance Rocket Nozzle Materials," NASA CR-134806, 1975.

10. E.N.C. Dalder, W. Ludemann, and B. Schumacher, "Thermal stability of four high-strength, high-conductivity copper sheet alloys," UCRL-88919, and ASM's Copper and Copper Alloys Conf., 1983, material also appears in UCRL-89034-Rev. 1, Conf-830466-Rev-1, DE83 013312 Accession No. 84N10288, DOE Workshop on Copper Alloys, 1983.

11. J.J. Stephens, R.J. Bourcier, F.J. Vigil, and D.T. Schmale, "Mechanical properties of dispersion strengthened copper: a comparison of braze cycle annealed and coarse grain microstructure," Sandia Report SAND88-1351, 1988.

12. Metals Handbook, 9th ed., Properties and Selection: Nonferrous Alloys and Pure Metals, ASM Handbook Committee, American Soc. for Metals, Metals Park, OH, 1979, 2, p. 309.

13. J.B. Correia, H.A. Davies, and C.M. Sellars, "Strengthening in rapidly solidified age hardened $\mathrm{Cu}-\mathrm{Cr}$ and $\mathrm{Cu}-\mathrm{Cr}-\mathrm{Zr}$ alloys," Acta mater., 45, (1), 1997, pp. 177-190.

14. T. Nguyentat, V.A. Gibson, and R.M. Horn, "NASA-Z A liner material for rocket combustion chambers," $27^{\text {th }}$ Joint Prop. Conf., AIAA Paper No. 91-2487.

15. D.L. Ellis, "GRCop-84: A high-temperature copper alloy for high-heat-flux application,” NASA/TM-2005-213566.

16. K..J. Zeng, M. Hamalainen, and K. Lilius, "Phase relationships in Cu-rich corner of the Cu-Cr-Zr phase diagram," Scripta Metallurgica et Materialia, 32, (12), 1995, pp. 2009-2014.

17. Pratt \& Whitney Aircraft Group: "Thrust Chamber Material Technology Program," NASA CR-187207, 1989.

18. S.J. Zinkle, "Tensile properties of high-strength, high-conductivity copper alloys at high temperatures," in Fusion Materials Semiann. Prog. Report for period ending June 30, 2000, DOE/ER-0313/28, Oak Ridge National Lab, Oak Ridge, TN, 2000, pp. $171-175$.

19. J.M. Kazaroff and G.A. Repas, "Conventionally Cast and Forged Copper Alloy for High Heat Flux Thrust Chambers," NASA Technical Paper 2694, NASA Glenn Research Center, Cleveland OH, 1987.

20. H.C. de Groh III, D.L. Ellis, and W.S. Loewenthal, "Comparison of GRCop-84 to other High Thermal Conductive Cu Alloys," NASA/TM-2007-214663, NASA Glenn Research Center, Cleveland, OH, 2007.

21. D.L. Ellis and R.L. Dreshfield, "Preliminary evaluation of a powder metal copper-8 Cr-4 Nb alloy," in Advanced Earth-toOrbit Propulsion Technology 1992, NASA CP-3174, 1, NASA Marshall Space Flight Center, Huntsville, AL, May 1992, pp. 18-27.

22. D.L. Ellis, R.L. Dreshfield, M.J. Verrilli, and D.G. Ulmer, "Mechanical Properties of a Cu-8 Cr-4 Nb alloy," in Advanced Earth-to-Orbit Propulsion Technology 1994, NASA CP-3282, NASA Marshall Space Flight Center, Huntsville, AL, May 1994, pp. 32-41.

23. D.L. Ellis and G.M. Michal, "Mechanical and thermal properties of two Cr-Cr-Nb alloys and NARloy-Z" NASA CR198529, NASA Glenn Research Center, Cleveland OH, Oct. 1996.

24. D.L. Ellis, W.S. Loewenthal, and H. Haller, "Creep of Commercially Produced GRCop-84," NASA TM to be published, NASA Glenn Research Center, Cleveland, OH, 2007.

25. A. Goldsmith, T.E. Waterman, and H.J. Hirschhorn, Handbook of Thermophysical Properties of Solid Materials, 1, Pergamon, New York, NY, 1961.

26. D.L. Ellis and G.M. Michal, "Formation of $\mathrm{Cr}$ and $\mathrm{Cr}_{2} \mathrm{Nb}$ precipitates in rapidly solidified $\mathrm{Cu}-\mathrm{Cr}-\mathrm{Nb}$ ribbon," Ultramicroscopy, 30, (1-2), June 1989, pp. 210-216.

27. J.D. Verhoeven, Fundamentals of Physical Metallurgy, John Wiley \& Sons pub., 1975, p. 330, 459, $515-517$.

28. ASM Handbook, 8, Mechanical Testing and Evaluation, H. Kuhn and D. Medlin, eds., ASM International, 2000, pp. 363368.

29. D.L. Ellis and D.J. Keller, “Thermophysical Properties of GRCop-84,” NASA/CR-2000-210055, NASA Glenn Research Center, Cleveland, OH, June 2000. 
Table 1 Composition of $\mathrm{Cu}$ alloys in weight percent.

\begin{tabular}{|l|c|c|c|c|c|c|}
\hline \multicolumn{1}{|c|}{ Alloy } & $\mathrm{Cr}$ & $\mathrm{Nb}$ & $\mathrm{Zr}$ & $\mathrm{Al}$ & $\mathrm{O}$ & $\mathrm{Ag}$ \\
\hline GRCop-84 & 6.65 & 5.85 & & & & \\
\hline AMZIRC (C15000) & & & 0.15 & & & \\
\hline GlidCop Al-15(C15715) & & & & 0.15 & 0.17 & \\
\hline $\mathrm{Cu}-0.9 \mathrm{Cr}(\mathrm{C} 18200)$ & 0.9 & & & & & \\
\hline $\mathrm{Cu}-1 \mathrm{Cr}-0.1 \mathrm{Zr}(\mathrm{C} 18150)$ & 1.0 & & 0.1 & & & \\
\hline NARloy-Z & & & 0.5 & & & 3.0 \\
\hline
\end{tabular}

Table 2 Simulated braze heat treatment.

\begin{tabular}{|c|l|}
\hline Stage & \multicolumn{1}{|c|}{ Action } \\
\hline 1 & Raise temperature from 25 to $935^{\circ} \mathrm{C}$ \\
\hline 2 & Hold at $935^{\circ} \mathrm{C}$ for $22.5 \pm 2.5 \mathrm{~min}$ \\
\hline 3 & Lower temperature from 935 to $871^{\circ} \mathrm{C}$ at $1.7^{\circ} \mathrm{C} / \mathrm{min}$ \\
\hline 4 & Lower temperature from 871 to $538^{\circ} \mathrm{C}$ at $2.8^{\circ} \mathrm{C} / \mathrm{min}$ \\
\hline 5 & Free cool to room temperature and remove specimen from furnace \\
\hline
\end{tabular}

Table 3 Power function constants for step loaded, secondary steady state creep; creep rate power functions of the form $\dot{\varepsilon}=A \sigma^{n}$ where $A$ and $n$ are given in the table, $\dot{\varepsilon}$ is creep rate in units of $\sec ^{-1}$, and $\sigma$ is step loaded creep stress in units of MPa.

\begin{tabular}{|c|c|c|}
\hline & $A$ & $n$ \\
\hline GRCop- 84 as-received, $500^{\circ} \mathrm{C}$ & $4.77 \mathrm{E}-26$ & 9.49 \\
\hline GRCop- 84 as-received, $650^{\circ} \mathrm{C}$ & $7.17 \mathrm{E}-24$ & 10.32 \\
\hline GRCop- 84 as-received, $800^{\circ} \mathrm{C}$ & $2.63 \mathrm{E}-18$ & 8.67 \\
\hline AMZIRC as-received, $500^{\circ} \mathrm{C}$ & $4.15 \mathrm{E}-20$ & 6.70 \\
\hline AMZIRC Brazed, $500^{\circ} \mathrm{C}$ & $4.18 \mathrm{E}-13$ & 3.73 \\
\hline AMZIRC as-received, $650^{\circ} \mathrm{C}$ & $*$ & $*$ \\
\hline AMZIRC Brazed, $650^{\circ} \mathrm{C}$ & $2.99 \mathrm{E}-11$ & 3.65 \\
\hline GlidCop as-received, $500{ }^{\circ} \mathrm{C}$ & $7.71 \mathrm{E}-57$ & 22.93 \\
\hline GlidCop Brazed, $500^{\circ} \mathrm{C}$ & $3.72 \mathrm{E}-34$ & 12.40 \\
\hline GlidCop as-received, $650^{\circ} \mathrm{C}$ & $4.58 \mathrm{E}-39$ & 15.90 \\
\hline GlidCop Brazed, $650^{\circ} \mathrm{C}$ & $8.48 \mathrm{E}-38$ & 15.50 \\
\hline $\mathrm{Cu}-1 \mathrm{Cr}-0.1 \mathrm{Zr}$ as-received, $500{ }^{\circ} \mathrm{C}$ & $1.47 \mathrm{E}-19$ & 5.59 \\
\hline $\mathrm{Cu}-1 \mathrm{Cr}-0.1 \mathrm{Zr}$ Brazed $500{ }^{\circ} \mathrm{C}$ & $5.94 \mathrm{E}-17$ & 5.71 \\
\hline $\mathrm{Cu}-1 \mathrm{Cr}-0.1 \mathrm{Zr}$ as-received $650{ }^{\circ} \mathrm{C}$ & $1.01 \mathrm{E}-13$ & 5.03 \\
\hline $\mathrm{Cu}-1 \mathrm{Cr}-0.1 \mathrm{Zr}$ Brazed $650{ }^{\circ} \mathrm{C}$ & $1.50 \mathrm{E}-14$ & 5.52 \\
\hline $\mathrm{Cu}-0.9 \mathrm{Cr}$ as-received $500^{\circ} \mathrm{C}$ & $7.31 \mathrm{E}-18$ & 6.04 \\
\hline $\mathrm{Cu}-0.9 \mathrm{Cr}$ Brazed, $500^{\circ} \mathrm{C}$ & $4.00 \mathrm{E}-14$ & 5.08 \\
\hline $\mathrm{Cu}-0.9 \mathrm{Cr}$ as-received $650^{\circ} \mathrm{C}$ & $*$ & $*$ \\
\hline $\mathrm{Cu}-0.9 \mathrm{Cr}$ Brazed $650^{\circ} \mathrm{C}$ & $1.27 \mathrm{E}-10$ & 3.83 \\
\hline
\end{tabular}

*Insufficient data to obtain constant 
Table 4 Power function constants for constant load, secondary, steady state tensile creep at elevated temperatures; creep rate power functions of the form $\dot{\varepsilon}=A \sigma^{n}$ where $A$ and $n$ are given in the table, $\dot{\varepsilon}$ is creep rate in units of $\sec ^{-1}$, and $\sigma$ is constant load creep stress in units of $\mathrm{MPa}$.

\begin{tabular}{|l|c|c|}
\hline & $A$ & $n$ \\
\hline GRCop-84, $500{ }^{\circ} \mathrm{C}$ & $1.042 \mathrm{E}-22$ & 7.67 \\
\hline GRCop-84 $650{ }^{\circ} \mathrm{C}$ & $3.400 \mathrm{E}-21$ & 8.52 \\
\hline GRCop84 $800{ }^{\circ} \mathrm{C}$ & $1.078 \mathrm{E}-16$ & 7.3 \\
\hline Amzirc as-received, $500{ }^{\circ} \mathrm{C}$ & $8.919 \mathrm{E}-13$ & 2.35237 \\
\hline Amzirc Brazed, $500{ }^{\circ} \mathrm{C}$ & $1.633 \mathrm{E}-23$ & 9.48610 \\
\hline Amzirc as-received, $650{ }^{\circ} \mathrm{C}$ & $2.638 \mathrm{E}-10$ & 3.55738 \\
\hline Amzirc Brazed, $650{ }^{\circ} \mathrm{C}$ & $2.141 \mathrm{E}-17$ & 7.80399 \\
\hline GlidCop as-received, $500{ }^{\circ} \mathrm{C}$ & $2.392 \mathrm{E}-87$ & 36.40497 \\
\hline GlidCop Brazed, $500{ }^{\circ} \mathrm{C}$ & $1.195 \mathrm{E}-205$ & 91.21151 \\
\hline GlidCop as-received, $650{ }^{\circ} \mathrm{C}$ & $3.312 \mathrm{E}-61$ & 26.74301 \\
\hline GlidCop Brazed, $650{ }^{\circ} \mathrm{C}$ & $2.762 \mathrm{E}-56$ & 24.69575 \\
\hline $\mathrm{CuCrZr}$ as-received, $500{ }^{\circ} \mathrm{C}$ & $6.857 \mathrm{E}-20$ & 5.46637 \\
\hline $\mathrm{CuCrZr}$ Brazed $500{ }^{\circ} \mathrm{C}$ & $2.489 \mathrm{E}-14$ & 4.46268 \\
\hline $\mathrm{CuCrZr}$ as-received $650{ }^{\circ} \mathrm{C}$ & $4.040 \mathrm{E}-10$ & 2.13871 \\
\hline $\mathrm{CuCrZr}$ Brazed $650{ }^{\circ} \mathrm{C}$ & $8.059 \mathrm{E}-17$ & 7.07106 \\
\hline $\mathrm{CuCr}$ as-received $500{ }^{\circ} \mathrm{C}$ & $6.353 \mathrm{E}-13$ & 3.01887 \\
\hline $\mathrm{CuCr}$ Brazed, $500{ }^{\circ} \mathrm{C}$ & $7.363 \mathrm{E}-13$ & 4.17238 \\
\hline $\mathrm{CuCr}$ as-received $650^{\circ} \mathrm{C}$ & $*$ & $*$ \\
\hline $\mathrm{CuCr}$ Brazed $650{ }^{\circ} \mathrm{C}$ & $6.047 \mathrm{E}-11$ & 4.05855 \\
\hline
\end{tabular}

*Did not follow power law creep.

Table 5 Thermal expansion of AMZIRC, GlidCop Al-15, Cu-1Cr-0.1Zr, and $\mathrm{Cu}-0.9 \mathrm{Cr}$ alloys where the thermal expansion, $\alpha$, in units of in/in, is expressed as a quadratic function of temperature, $T$, in units of ${ }^{\circ} \mathrm{C}$, such that $\alpha(T)=\mathrm{A}(T)^{2}+B(T)+C$. Based on the variations of $\alpha$ expressed among different specimens, $\alpha$ values are estimated to be accurate to within $\pm 1 \%$.

\begin{tabular}{|l|c|c|c|}
\hline \multicolumn{1}{|c|}{ Alloy } & A & B & C \\
\hline AMZIRC & $4.132 \mathrm{E}-09$ & $1.610 \mathrm{E}-05$ & $-1.701 \mathrm{E}-04$ \\
\hline GlidCop Al-15 & $3.989 \mathrm{E}-09$ & $1.619 \mathrm{E}-05$ & $-1.000 \mathrm{E}-04$ \\
\hline $\mathrm{Cu}-1 \mathrm{Cr}-0.1 \mathrm{Zr}$ & $4.947 \mathrm{E}-09$ & $1.559 \mathrm{E}-05$ & $-8.019 \mathrm{E}-05$ \\
\hline $\mathrm{Cu}-0.9 \mathrm{Cr}$ & $4.317 \mathrm{E}-09$ & $1.599 \mathrm{E}-05$ & $-1.016 \mathrm{E}-04$ \\
\hline
\end{tabular}


Table 6 Summary and comparison of alloy properties.

\begin{tabular}{|c|c|}
\hline Property & Comparison \\
\hline $\begin{array}{l}\text { Thermal } \\
\text { conductivity }\end{array}$ & $\begin{array}{l}\text { The conductivity of oxygen free copper is about } 400 \mathrm{~W} / \mathrm{mK} \text {, all alloys of copper are below this value. } \\
\text { The conductivity of AMZIRC is best at about } 370 \mathrm{~W} / \mathrm{mK} \text {, the conductivity of GlidCop Al- } 15 \text { and } \\
\text { NARloy-Z is approximately } 320 \mathrm{~W} / \mathrm{mK} \text {, and that of GRCop- } 84 \text { is about } 300 \mathrm{~W} / \mathrm{mK} .^{[3]}\end{array}$ \\
\hline $\begin{array}{l}\text { Thermal } \\
\text { expansion }\end{array}$ & $\begin{array}{l}\text { The thermal expansion of GRCop- } 84 \text { is the lowest at } 0.008 \mathrm{in} / \mathrm{in} \text { at } 480{ }^{\circ} \mathrm{C} \text {; the expansion of GlidCop, } \\
\text { AMZIRC, } \mathrm{Cu}-1 \mathrm{Cr}-0.1 \mathrm{Zr} \text {, and } \mathrm{Cu}-0.9 \mathrm{Cr} \text { at this temperature are all about the same at } 0.0087 \mathrm{in} / \mathrm{in} \text {. }\end{array}$ \\
\hline Strength & $\begin{array}{l}\text { Since GlidCop and GRCop- } 84 \text { are not significantly influenced by high temperature brazing, these two } \\
\text { alloys are clearly stronger than the heat treatable alloys (AMZIRC, Cu-1Cr- } 0.1 \mathrm{Zr}, \mathrm{Cu}-0.9 \mathrm{Cr}, \mathrm{NARloy}-\mathrm{Z} \text { ) } \\
\text { after brazing. In the absence of any brazing heat treatment }-\mathrm{Cu}-1 \mathrm{Cr}-0.1 \mathrm{Zr} \text { is strongest, even at test } \\
\text { temperatures up to } 650^{\circ} \mathrm{C} \text {. However, the strength of } \mathrm{Cu}-1 \mathrm{Cr}-0.1 \mathrm{Zr} \text { is expected to degrade with time at } \\
\text { use temperatures in excess of } 500^{\circ} \mathrm{C} \text { due to over aging. }\end{array}$ \\
\hline $\begin{array}{l}\text { Compressive } \\
\text { strength }\end{array}$ & $\begin{array}{l}\text { Compressive strength in these alloys closely follows what was found for tensile strength. GlidCop Al-15 } \\
\text { and GRCop- } 84 \text { were the strongest after brazing. }\end{array}$ \\
\hline Ductility & $\begin{array}{l}\text { GRCop- } 84 \text {, AMZIRC, and } \mathrm{Cu}-1 \mathrm{Cr}-0.1 \mathrm{Zr} \text { all had good ductility. GRCop- } 84 \text { 's elongation was the most } \\
\text { consistent, remaining between about } 16 \text { and } 25 \% \text { across the entire temperature range tested }(20 \text { to } 800 \\
\left.{ }^{\circ} \mathrm{C}\right) \text {. GlidCop } \mathrm{Al}-15 \text { and } \mathrm{Cu}-0.9 \mathrm{Cr} \text { had the worst ductility at temperatures greater than } 500{ }^{\circ} \mathrm{C} \text {; the } \\
\text { ductility of } \mathrm{Cu}-0.9 \mathrm{Cr} \text { was particularly bad }(\sim 2 \% \text { elongation }) \text { at } 500 \text { and } 650{ }^{\circ} \mathrm{C} \text {. }\end{array}$ \\
\hline Creep & $\begin{array}{l}\text { GlidCop Al-15 had the best creep properties of all the alloys regardless of brazing condition. The creep } \\
\text { properties of as-received } \mathrm{Cu}-1 \mathrm{Cr}-0.1 \mathrm{Zr} \text { were as good as GlidCop's, however, the creep rates of } \mathrm{Cu}-1 \mathrm{Cr}- \\
0.1 \mathrm{Zr} \text {, AMZIRC, and } \mathrm{Cu}-0.9 \mathrm{Cr} \text { dropped dramatically after the brazing heat treatment. The creep } \\
\text { properties of NARloy-Z were relatively poor. Thus after brazing, GRCop- } 84 \text { and GlidCop } \mathrm{Al}-15 \mathrm{had} \\
\text { better creep properties than the other alloys. In the brazed condition, at a strain rate of } 10^{-6} \mathrm{sec}^{-1} \text { the step } \\
\text { loaded creep stress for GlidCop Al- } 15 \text { was about } 160 \mathrm{MPa} \text {; at these same conditions the creep stress was } \\
\text { about } 110 \mathrm{MPa} \text { for GRCop- } 84 \text {, and about } 60 \mathrm{MPa} \text { for the other three alloys, including as-received } \\
\text { NARloy-Z. }\end{array}$ \\
\hline $\begin{array}{l}\text { Effects of } \\
\text { Brazing }\end{array}$ & $\begin{array}{l}\text { GRCop- } 84 \text { and GlidCop Al- } 15 \text { were not significantly affected by the simulated braze. AMZIRC, Cu- } 1 \mathrm{Cr}- \\
0.1 \mathrm{Zr} \text {, and } \mathrm{Cu}-0.9 \mathrm{Cr} \text { lost their strength due to the braze, with strengths dropping by about } 80 \% \text { or more } \\
\text { (yield strength loss was about } 50 \% \text { due to the braze in NARloy-Z). }\end{array}$ \\
\hline
\end{tabular}




\section{Figure Captions}

Fig. 1 Typical as-extruded GRCop-84 microstructures.

Fig. 2 AMZIRC longitudinal microstructures in the as-received condition; longitudinal/drawing direction is horizontal; dark spots are likely $\mathrm{Cu}_{5} \mathrm{Zr}$.

Fig. 3 AMZIRC longitudinal microstructures after the simulated brazing heat treatment at $935{ }^{\circ} \mathrm{C}$; longitudinal/ drawing direction is horizontal.

Fig. 4 GlidCop Al-15 longitudinal micrograph of the as-received condition; longitudinal/drawing direction is horizontal.

Fig. 5 GlidCop Al-15 longitudinal microstructures after the simulated brazing heat treatment at $935^{\circ} \mathrm{C}$; longitudinal/drawing direction is horizontal.

Fig. $6 \mathrm{Cu}-1 \mathrm{Cr}-0.1 \mathrm{Zr}$ micrograph of the as-received condition.

Fig. $7 \mathrm{Cu}-1 \mathrm{Cr}-0.1 \mathrm{Zr}$ longitudinal microstructures after the simulated brazing heat treatment at $935{ }^{\circ} \mathrm{C}$; longitudinal/drawing direction is horizontal.

Fig. $8 \mathrm{Cu}-0.9 \mathrm{Cr}$ micrographs of the as-received condition.

Fig. $9 \mathrm{Cu}-0.9 \mathrm{Cr}$ micrograph of the brazed condition.

Fig. 10 Ultimate tensile stress for as-received and brazed GRCop-84, AMZIRC, GlidCop Al-15, Cu-1Cr-0.1Zr, and Cu-0.9Cr alloys. GRCop-84 values are the average of HIPed and extruded material, data points represent averages of multiple tests, five tests at each temperature for GRCop-84, most others are the average of two tests. Average values for NARloy-Z taken from the literature are shown as a dashed line. ${ }^{[9,14,15,21]}$

Fig. 11 Yield Strength, in units of MPa, at $0.2 \%$ off-set strain for as-received and brazed GRCop-84, AMZIRC, GlidCop Al$15, \mathrm{Cu}-1 \mathrm{Cr}-0.1 \mathrm{Zr}$, and $\mathrm{Cu}-0.9 \mathrm{Cr}$ alloys. GRCop- 84 values are the average of HIPed and extruded material, data points represent averages of multiple tests, five tests at each temperature for GRCop-84, most others are the average of two tests. Average values for NARloy-Z taken from the literature are shown as dashed lines. ${ }^{[9,14,15,21]}$

Fig. 12 Elongation in tensile of as-received and braze heat treated GRCop-84, AMZIRC, GlidCop Al-15, Cu-1Cr-0.1Zr, and $\mathrm{Cu}-0.9 \mathrm{Cr}$ alloys. Data points represent averages of multiple tests, five tests at each temperature for GRCop-84, most others are the average of two tests.

Fig. 13 Reduction in cross-sectional area for as-received and brazed GRCop-84, AMZIRC, GlidCop Al-15, Cu-1Cr-0.1Zr, Cu$0.9 \mathrm{Cr}$ alloys. GRCop- 84 values are the average of HIPed and extruded material, data points represent averages of multiple tests, five tests at each temperature for GRCop-84, most others are the average of two tests.

Fig. 14 Compressive Yield Strength, defined as the compressive stress at $0.2 \%$ off-set strain, for GRCop-84, AMZIRC, GlidCop Al-15, Cu-1Cr-0.1Zr, and $\mathrm{Cu}-0.9 \mathrm{Cr}$ alloys at various test temperatures; data points are from averages of multiple tests, two or three tests at each temperature for each alloy.

Fig. 15 Step loaded creep rate data in the linear region of the $\log -\log$ plot of strain rate and applied stress, with superimposed power function; power function constants are given in Table 9 . All data at $500{ }^{\circ} \mathrm{C}$ are in black and use smaller symbols, data at 650 and $800{ }^{\circ} \mathrm{C}$ are gray or colored and use larger symbols.

Fig. 16 Constant load creep and resulting secondary creep strain rates with superimposed power law functions, power function constants shown in Table 11; data at $500{ }^{\circ} \mathrm{C}$ are black, larger like symbols are at the higher temperature. The GRCop-84 lines shown are from the power law creep rate equations presented in Table 11, from analysis of previous creep tests presented in Ref. 24. NARloy-Z data shown by dashed lines, and at $800{ }^{\circ} \mathrm{C}$ by a shaded line near the ordinate at $3 \times 10^{-6} / \mathrm{sec}$, were taken from Ref. 23.

Fig. 17 Thermal Expansion results, lines are plots of equation (1) and the quadratics from Table 5. 


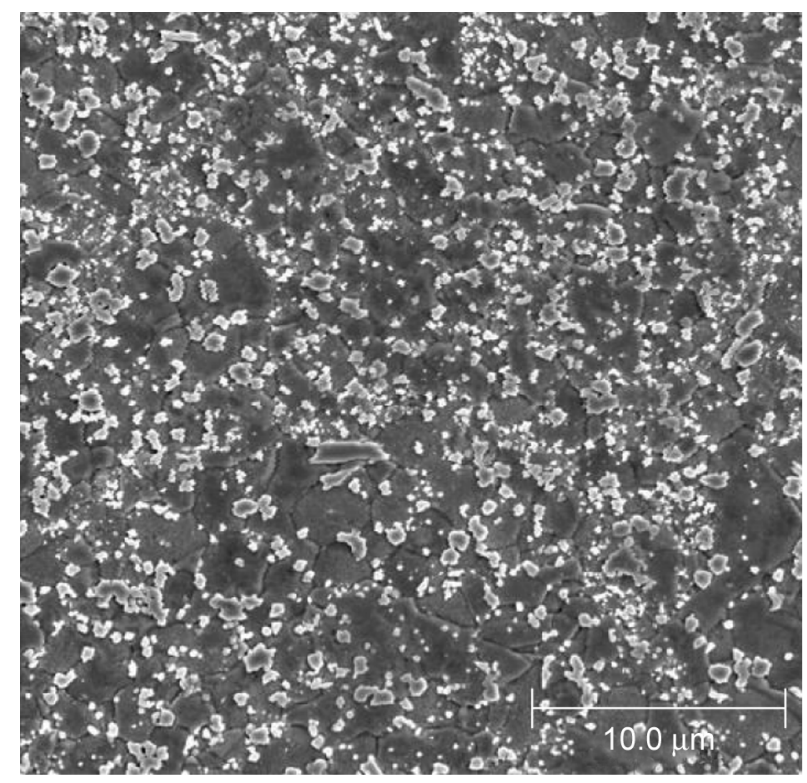

Figure 1
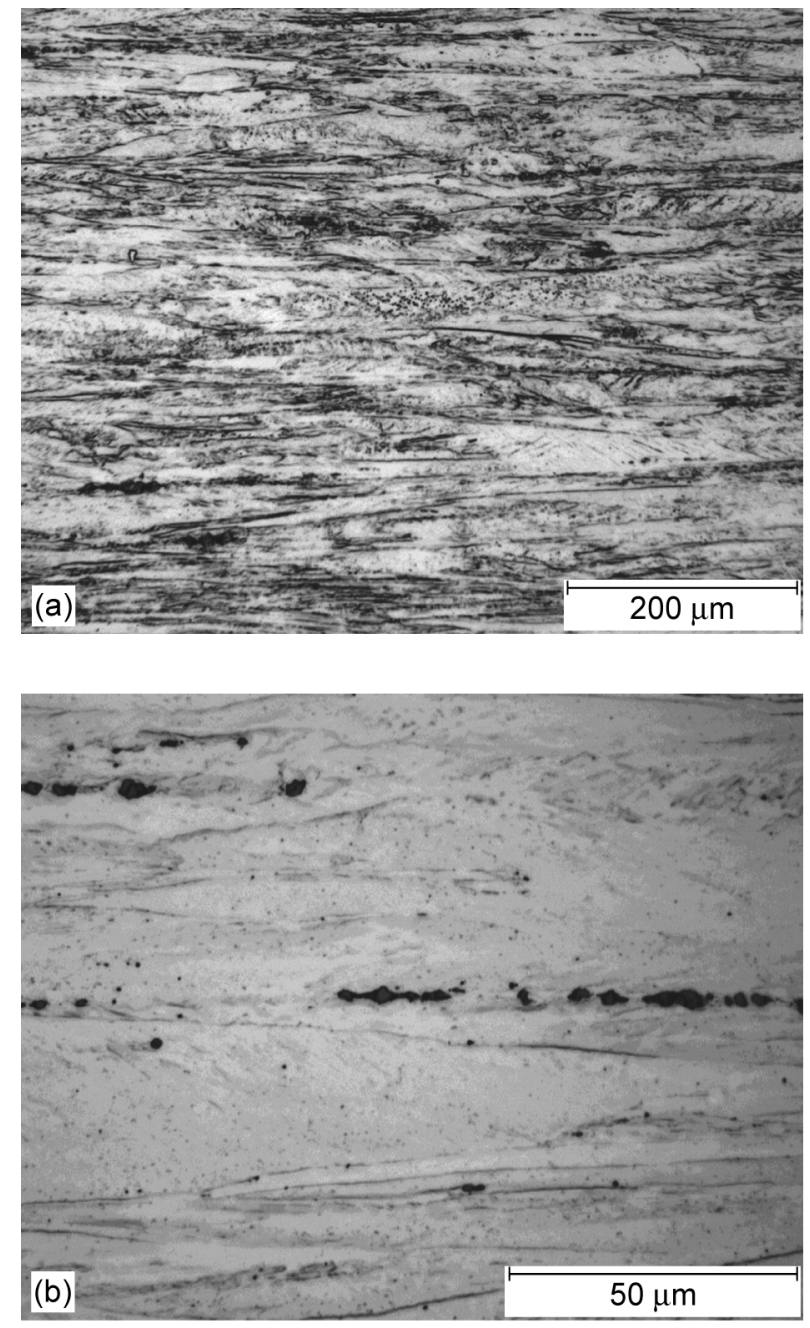

Figure 2 

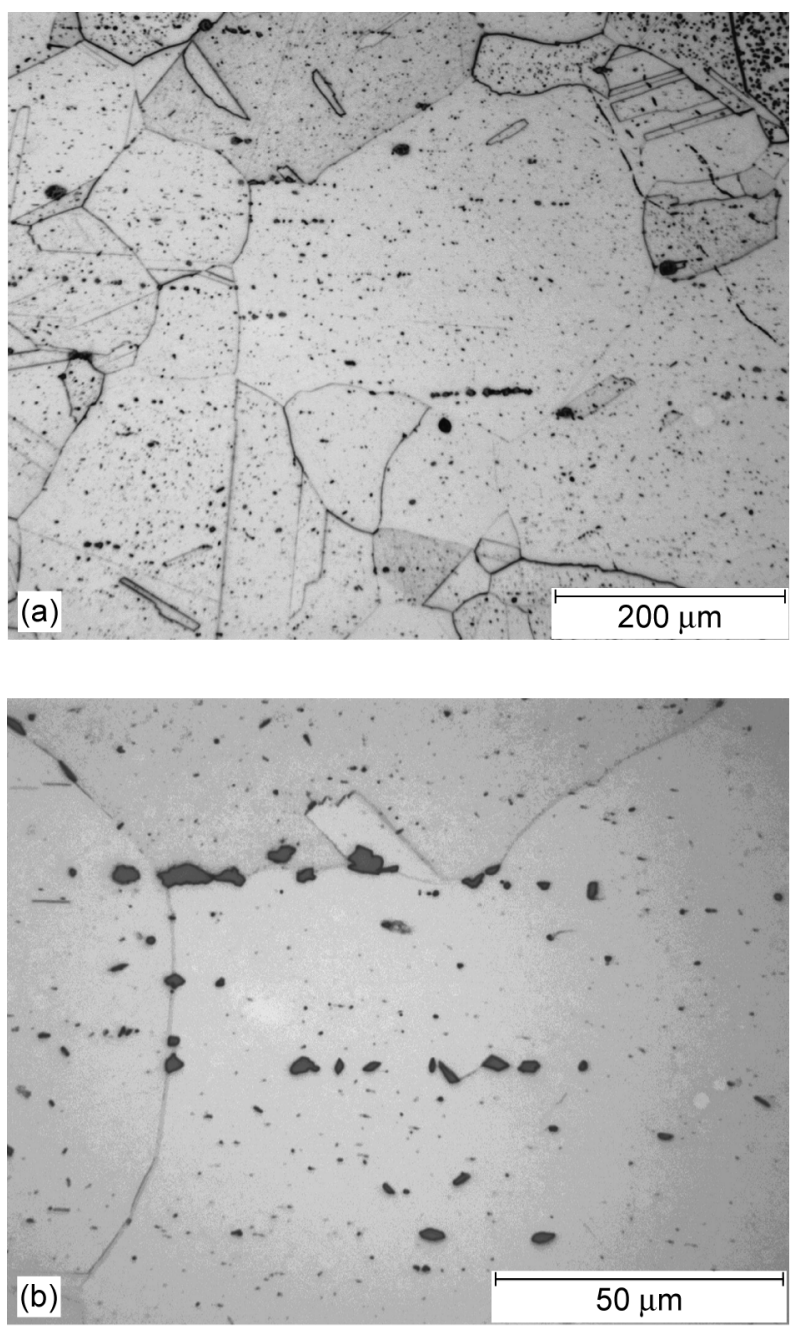

Figure 3 

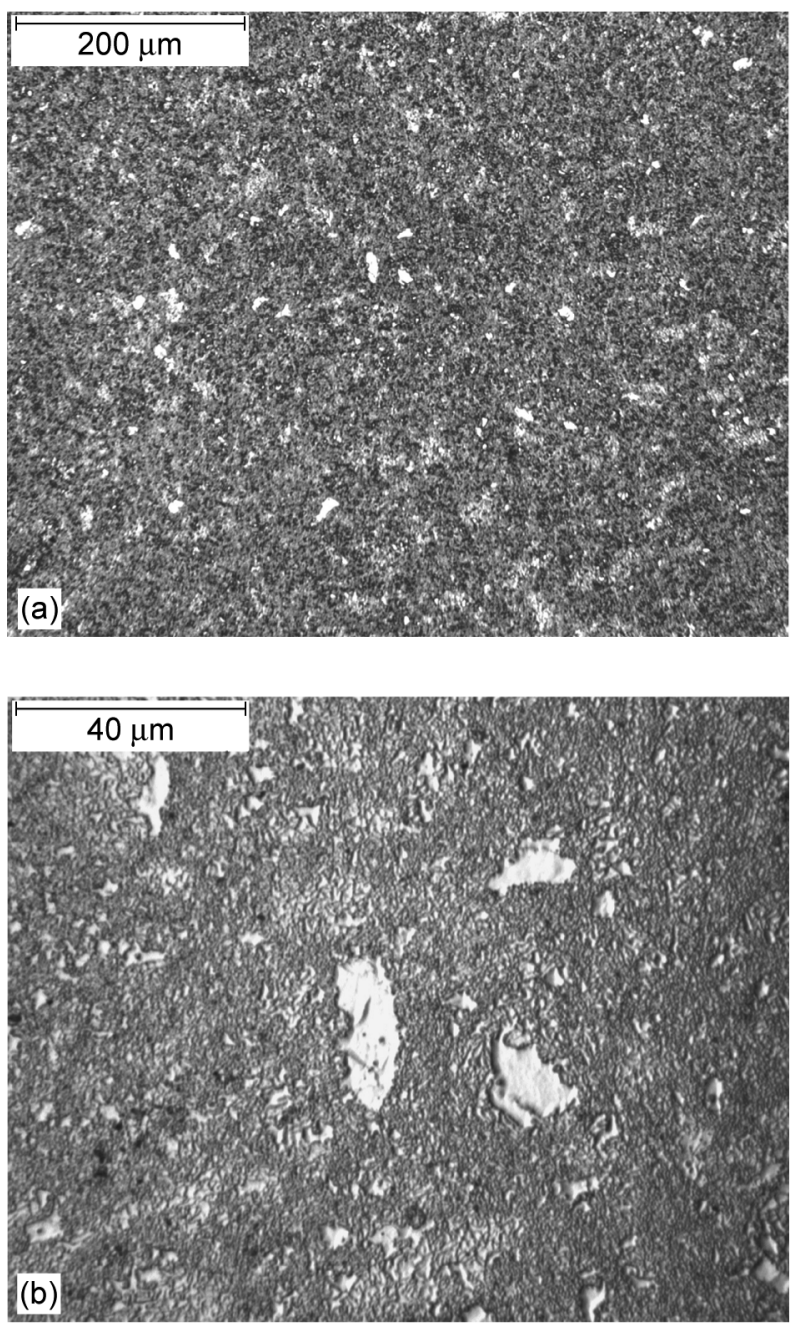

Figure 4 

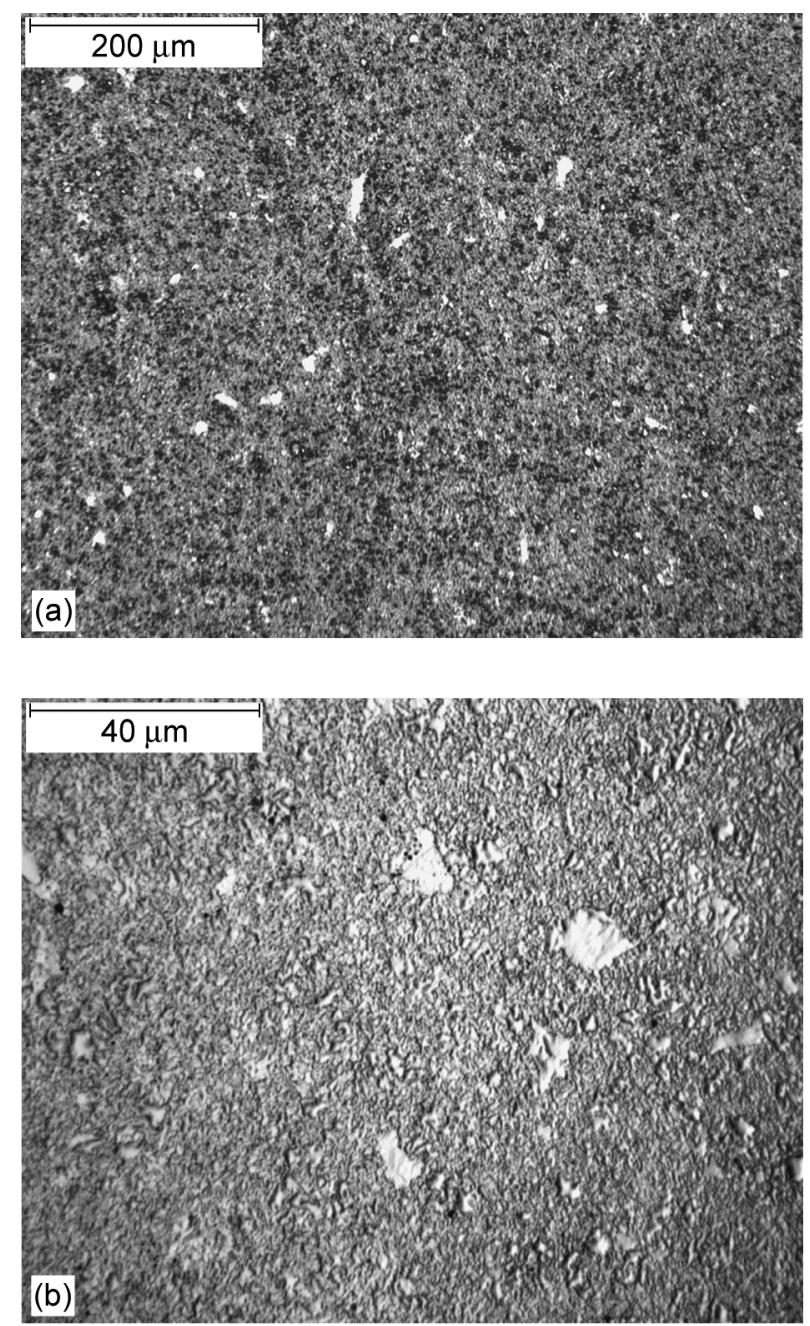

Figure 5 

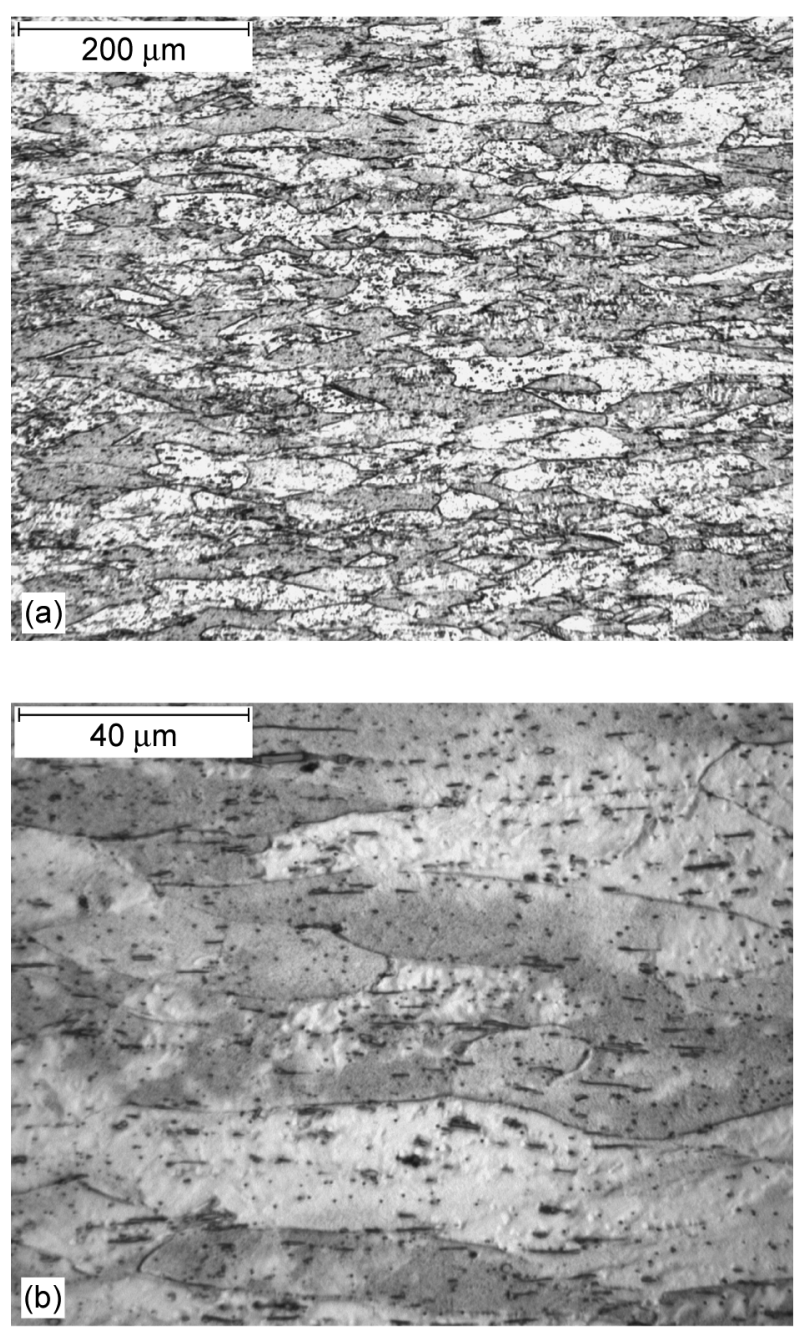

Figure 6 

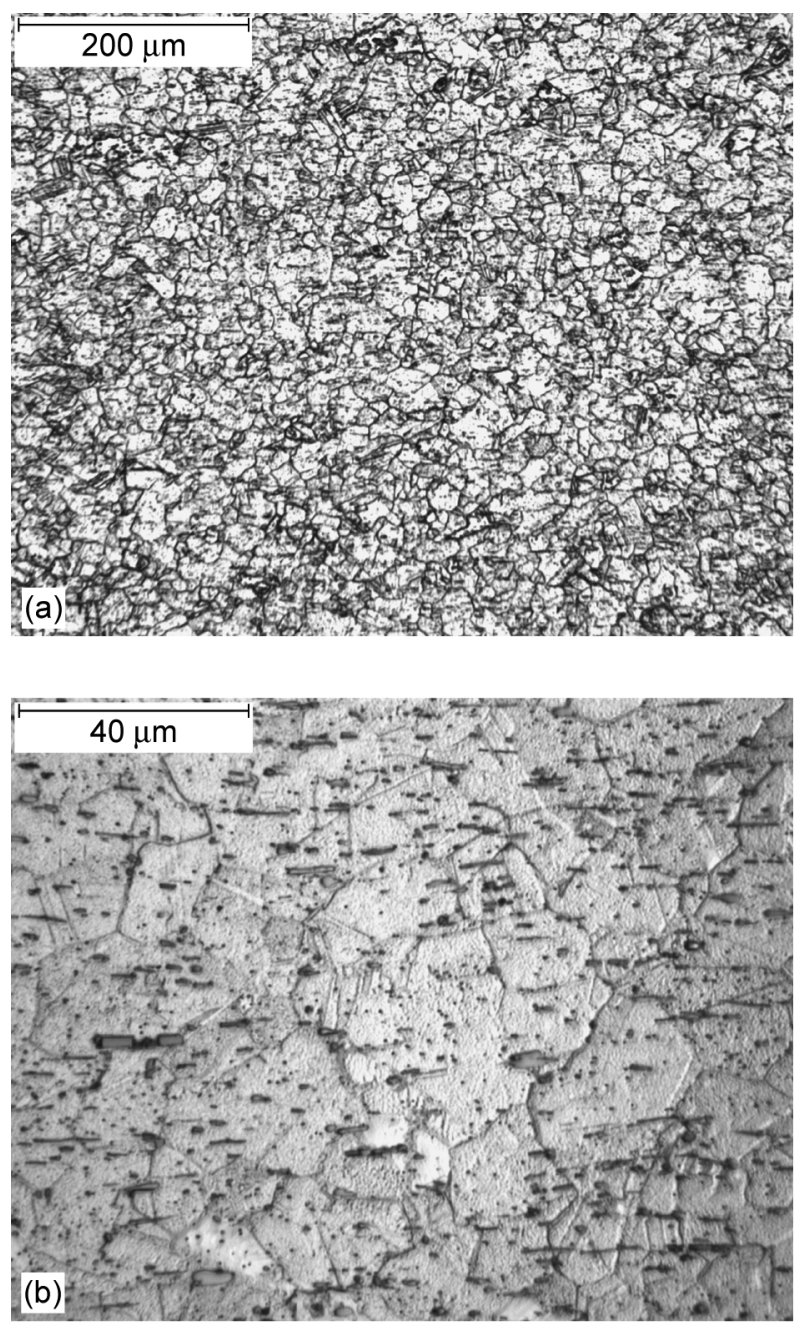

Figure 7 

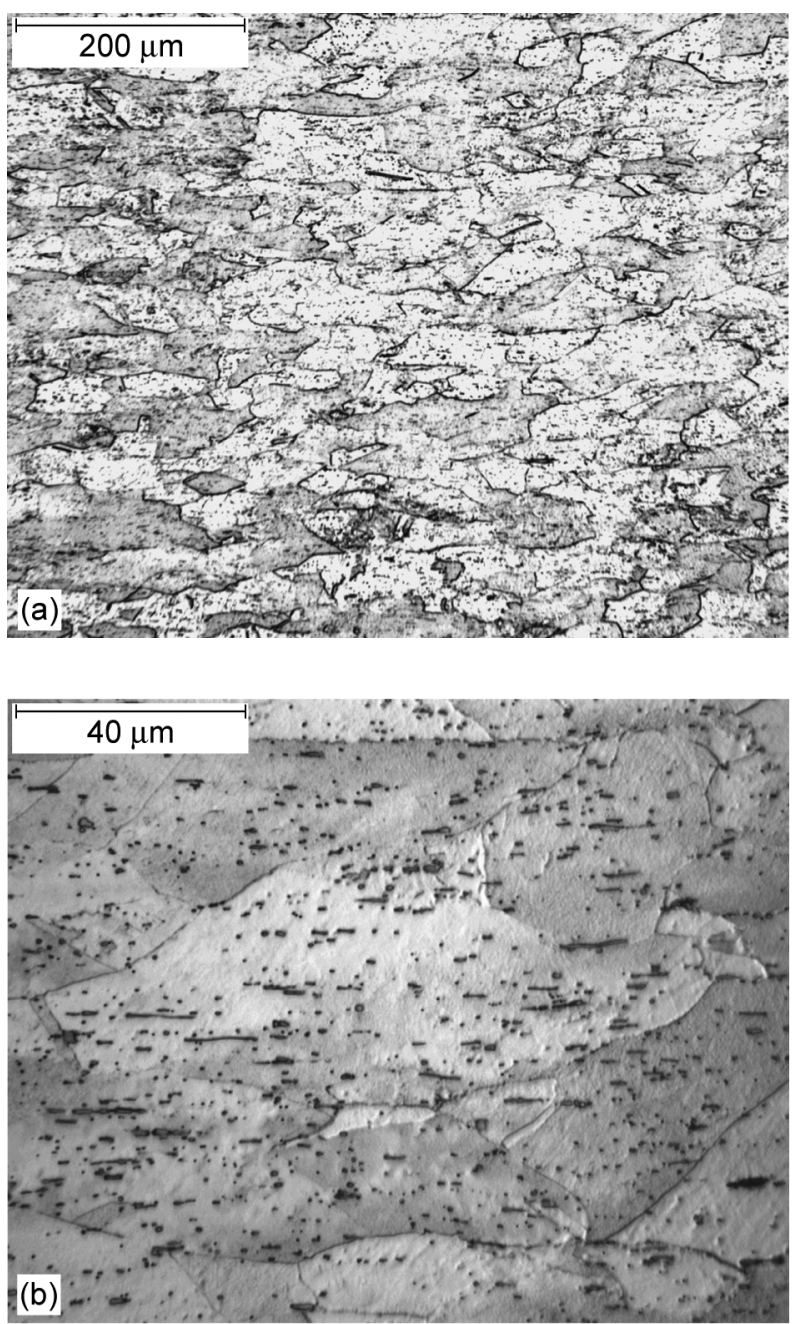

Figure 8 

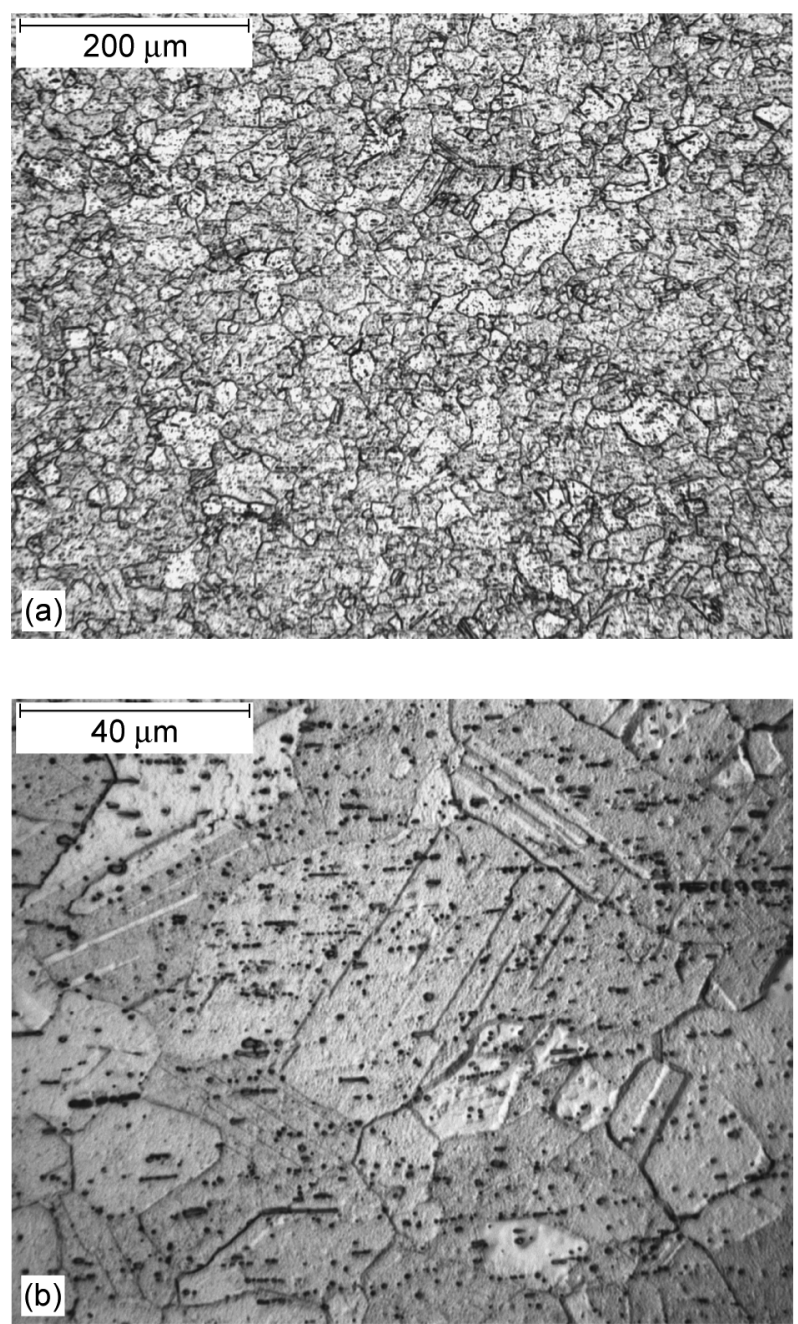

Figure 9 
$\because$ GRCop-84, as-received $\rightarrow$ CuCrZr, as-received

$\rightarrow$ GRCop-84, braze $935 \rightarrow \mathrm{CuCrZr}$, braze 935

$\triangle \mathrm{AMZIRC}$, as-received - $\mathrm{CuCr}$, as-received

- AMZIRC, braze $935 \quad *$ CuCr, braze 935

$\square$ GlidCop, as-received .... NARloy-Z, as-received

- GlidCop, braze 935

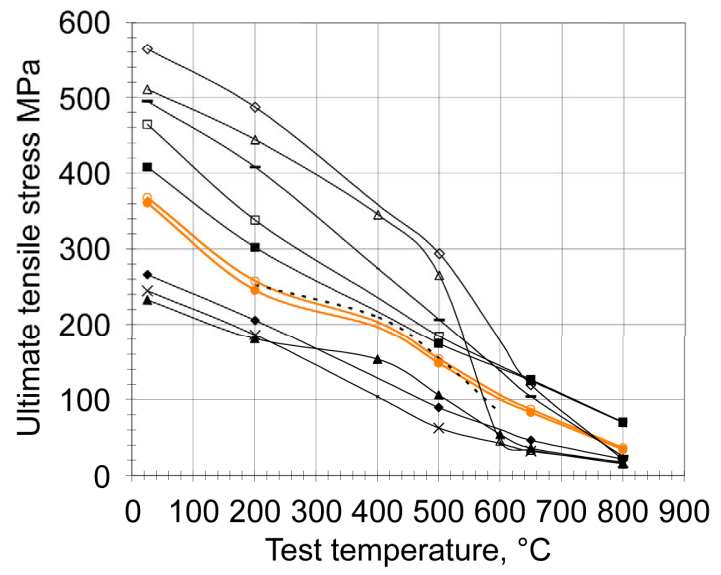

Figure 10
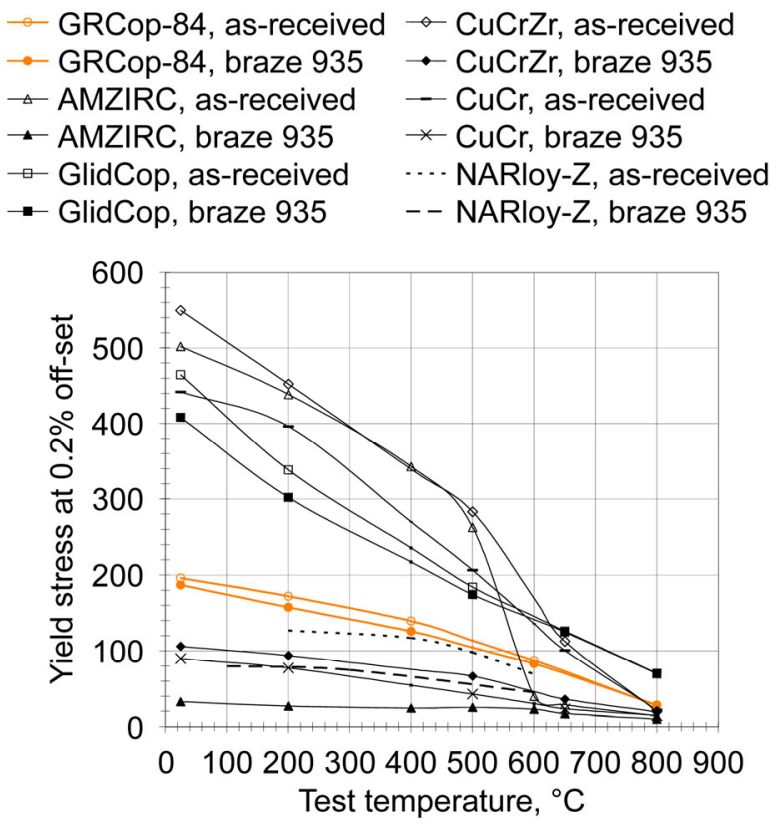

Figure 11 
- GRCop-84, as-received

- GRCop-84, braze 935

$\triangle$ AMZIRC, as-received

- AMZIRC, braze 935

$\rightarrow$ GlidCop, Al-15, as-received

- GlidCop, Al-15, braze 935

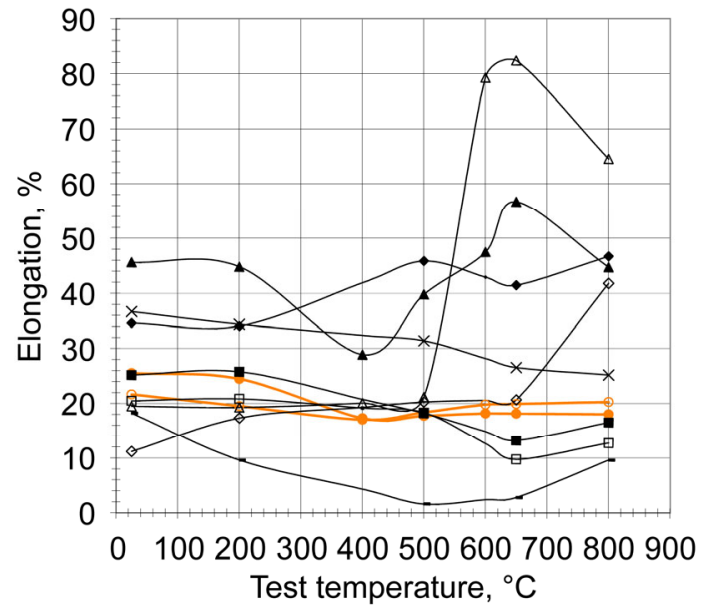

Figure 12

- GRCop-84, as-received

$\rightarrow$ GRCop-84, braze 935

$\triangle$ AMZIRC, as-received

- AMZIRC, braze 935

$\because$ GlidCop, Al-15, as-received

- GlidCop, Al-15, braze 935

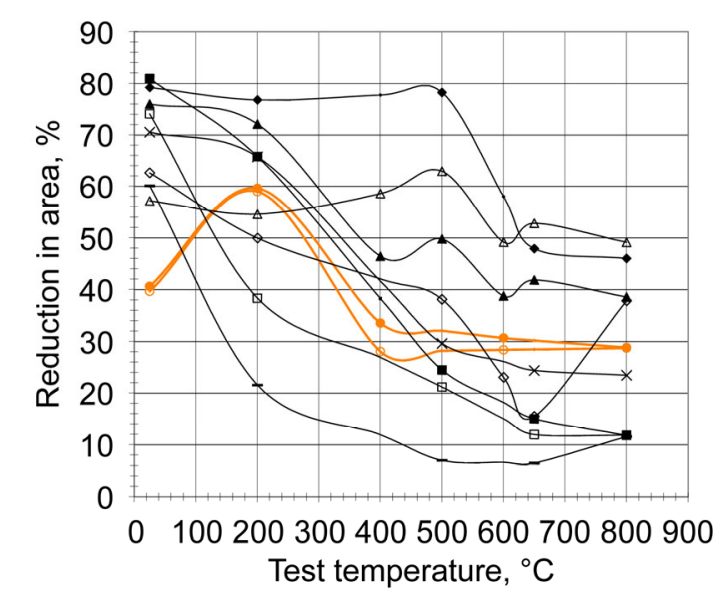

Figure 13
- CuCrZr, as-received

- $\mathrm{CuCrZr}$, braze 935

- CuCr, as-received

* CuCr, braze 935 $\rightarrow \mathrm{CuCrZr}$, as-received

- CuCrZr, braze 935

- CuCr, as-received

* CuCr, braze 935 
- GRCop-84, as-received $\rightarrow$ CuCrZr, as-received

$\triangle$ AMZIRC, as-received $\rightarrow$ CuCrZr, braze 935

- AMZIRC, braze 935 - CuCr, as-received

* GlidCop, as-received $\quad *$ CuCr, braze 935

- GlidCop, braze 935

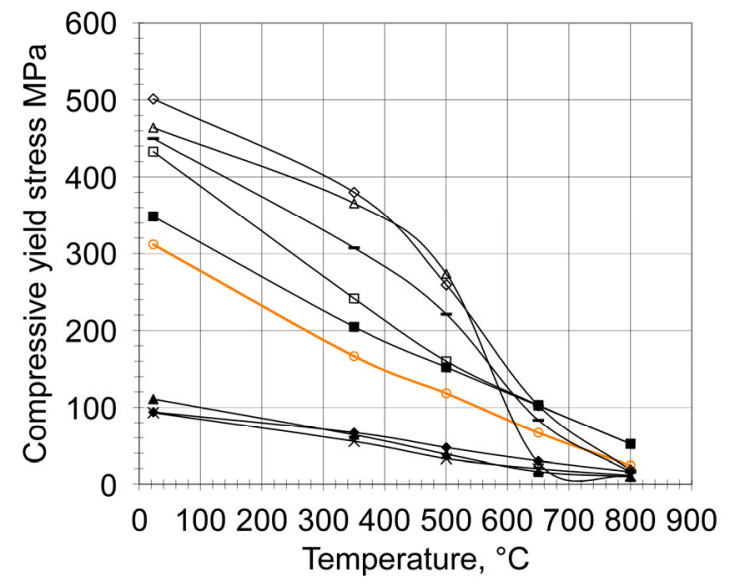

Figure 14

- GRCop-84, $500{ }^{\circ} \mathrm{C}$

- Rate equation

- GRCop- $84,650^{\circ} \mathrm{C}$

- Rate equation

- GRCop- $84,800^{\circ} \mathrm{C}$

- Rate equation

$\triangle$ AMZIRC, as-received, $500{ }^{\circ} \mathrm{C}$

- Rate equation

- AMZIRC, braze $935,500^{\circ} \mathrm{C}$

- Rate equation

$\triangle$ AMZIRC, as-received, $650^{\circ} \mathrm{C}$

$\triangle$ AMZIRC, braze $935,650^{\circ} \mathrm{C}$

- Rate equation

- GlidCop, as-received, $500^{\circ} \mathrm{C}$

- Rate equation

- GlidCop, braze $935,500{ }^{\circ} \mathrm{C}$

- Rate equation

ㅁ GlidCop, as-received, $650^{\circ} \mathrm{C}$

- Rate equation

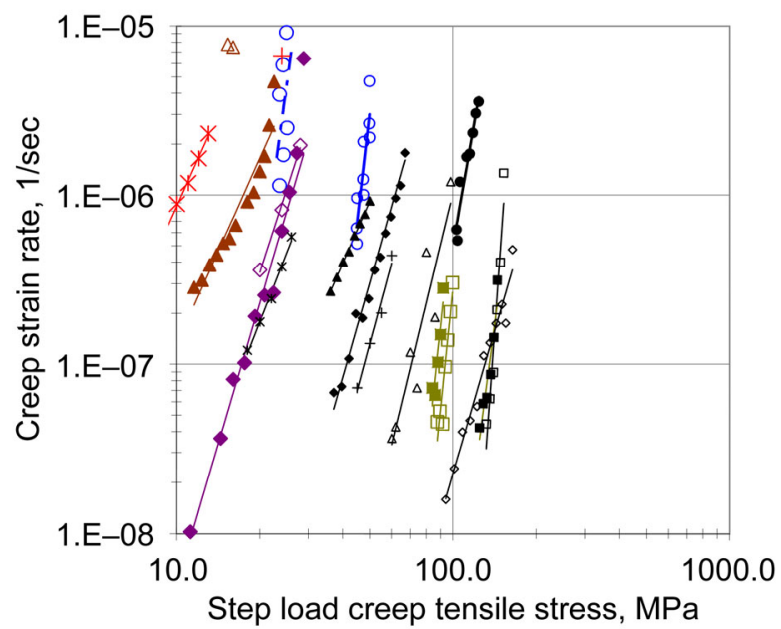

Figure 15 
ㅁ GlidCop, as-received, $500^{\circ} \mathrm{C}$

Rate equation

- GlidCop, brazed, $500^{\circ} \mathrm{C}$

Rate equation

$\square$ GlidCop, as-received, $650^{\circ} \mathrm{C}$

- Rate equation

- GlidCop, brazed, $650^{\circ} \mathrm{C}$

Rate equation

$\diamond \mathrm{CuCrZr}$, as-received, $500{ }^{\circ} \mathrm{C}$

- Rate equation

- CuCrZr, brazed, $500{ }^{\circ} \mathrm{C}$

- Rate equation

CuCrZr, as-received, $650^{\circ} \mathrm{C}$

Rate equation

- CuCrZr, brazed, $650{ }^{\circ} \mathrm{C}$

Rate equation

$\triangle$ AMZIRC, as-received, $500^{\circ} \mathrm{C}$

Rate equation

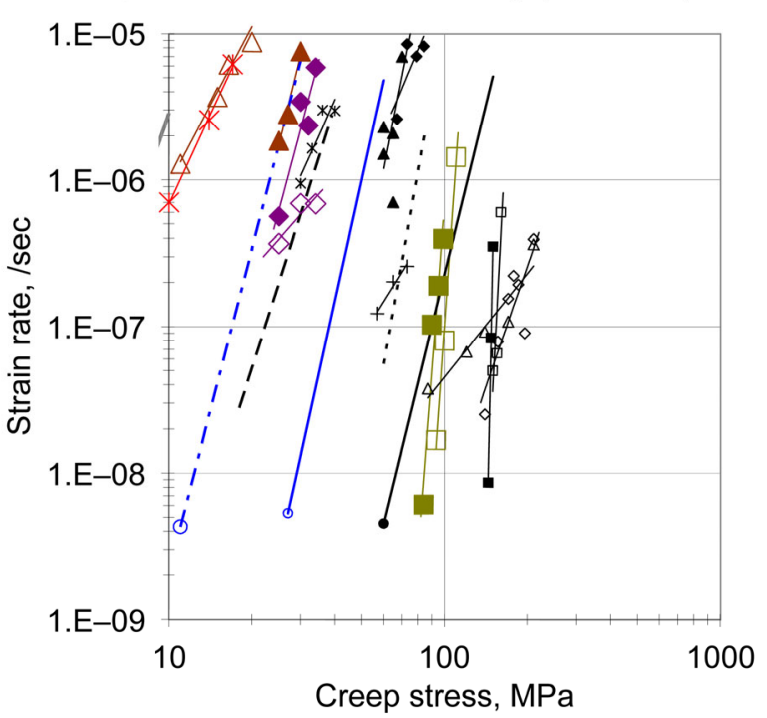

Figure 16

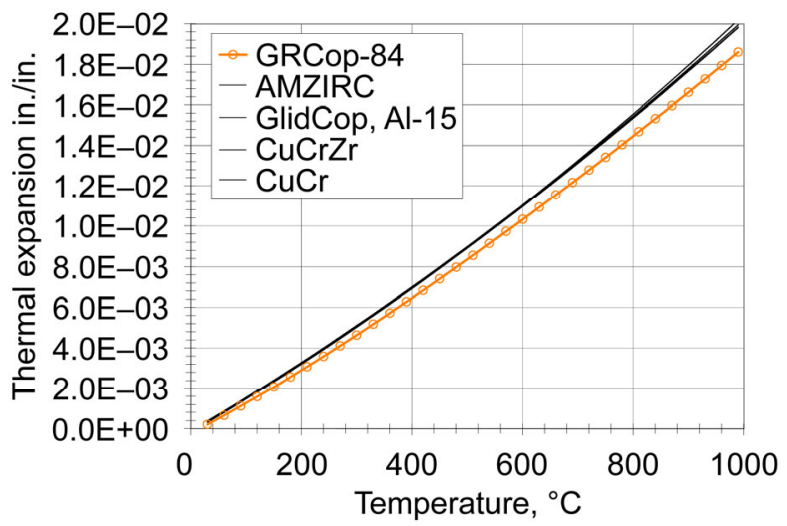

Figure 17

- AMZIRC, brazed, $500^{\circ} \mathrm{C}$ Rate equation

$\triangle$ AMZIRC, as-received, $650^{\circ} \mathrm{C}$

Rate equation

$\Delta$ AMZIRC, brazed, $650^{\circ} \mathrm{C}$

- Rate equation

$+\mathrm{CuCr}$, as-received, $500^{\circ} \mathrm{C}$

Rate equation

* CuCr, brazed, $500^{\circ} \mathrm{C}$

Rate equation

* CuCr, brazed, $650^{\circ} \mathrm{C}$

Rate equation

- GRCop-84, $500{ }^{\circ} \mathrm{C}$

- GRCop-84, $650^{\circ} \mathrm{C}$

$\multimap$ - GRCop-84, $800^{\circ} \mathrm{C}$

... NARloy-Z, as-received, $500^{\circ} \mathrm{C}$

- - NARloy-Z, as-received, $650^{\circ} \mathrm{C}$

NARloy-Z, as-received, $800^{\circ} \mathrm{C}$

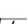

